\title{
\#USGS
}

Prepared in cooperation with the Missouri Department of Natural Resources

Temporal Changes in Nitrogen and Phosphorus Concentrations with Comparisons to Conservation Practices and Agricultural Activities in the Lower Grand River, Missouri and lowa, and Selected Watersheds, 1969-2015

Scientific livestigations Report 2017-5067.
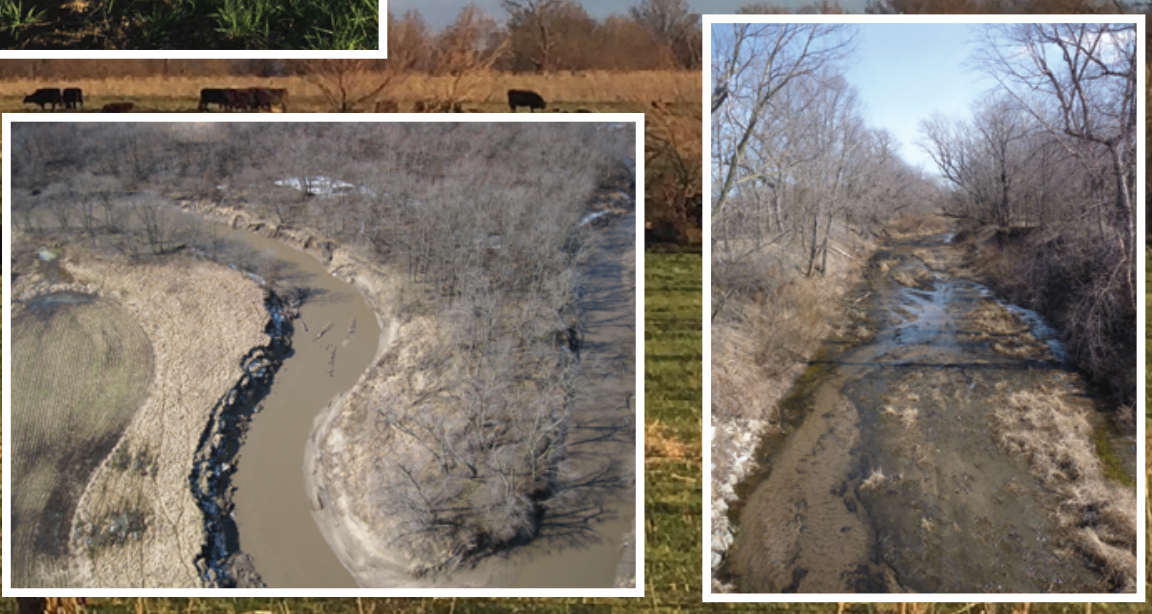

7inger (1) 
cover. Background photograph showing cattle in pasture within the Lower Grand River Basin, April 2017 (Photograph by Heather Krempa, U.S. Geological Survey). Top left. Photograph showing high streamflow at Medicine Creek near Laredo, Missouri, April 5, 2017 (Photograph by Heather Krempa, U.S. Geological Survey). Top Right. Photograph showing cropland within the Lower Grand River Basin, January 2017 (Photograph by Heather Krempa, U.S. Geological Survey).

Bottom left. Photograph showing the Grand River from an aerial view, February 2016 (Photograph by Greg Pitchford, Missouri Department of Conservation).

Bottom right. Photograph showing low streamflow at Little East Locust Creek near Browning, Missouri (Photograph by Heather Krempa, U.S. Geological Survey). 


\section{Temporal Changes in Nitrogen and Phosphorus Concentrations with Comparisons to Conservation Practices and Agricultural Activities in the Lower Grand River, Missouri and lowa, and Selected Watersheds, 1969-2015}

By Heather M. Krempa and Allison K. Flickinger

Prepared in cooperation with the

Missouri Department of Natural Resources

Scientific Investigations Report 2017-5067 


\title{
U.S. Department of the Interior \\ RYAN K. ZINKE, Secretary
}

\section{U.S. Geological Survey William H. Werkheiser, Acting Director}

\author{
U.S. Geological Survey, Reston, Virginia: 2017
}

For more information on the USGS - the Federal source for science about the Earth, its natural and living resources, natural hazards, and the environment-visit https://www.usgs.gov or call 1-888-ASK-USGS.

For an overview of USGS information products, including maps, imagery, and publications,

visit https://store.usgs.gov.

Any use of trade, firm, or product names is for descriptive purposes only and does not imply endorsement by the U.S. Government.

Although this information product, for the most part, is in the public domain, it also may contain copyrighted materials as noted in the text. Permission to reproduce copyrighted items must be secured from the copyright owner.

Suggested citation:

Krempa, H.M., and Flickinger, A.K., 2017, Temporal changes in nitrogen and phosphorus concentrations with comparisons to conservation practices and agricultural activities in the Lower Grand River, Missouri and lowa, and selected watersheds, 1969-2015: U.S. Geological Survey Scientific Investigations Report 2017-5067, 28 p., https://doi. org/10.3133/sir20175067.

ISSN 2328-0328 (online) 


\section{Contents}

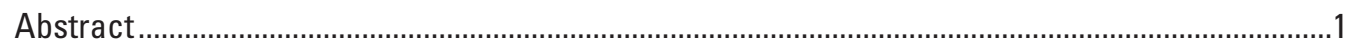

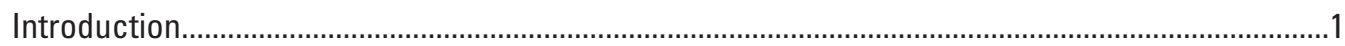

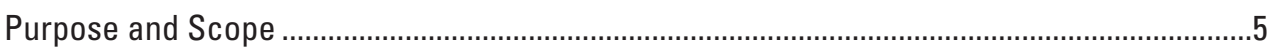

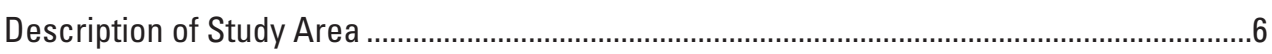

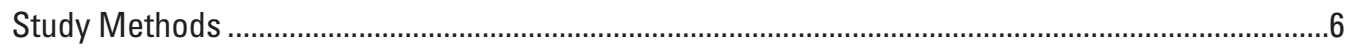

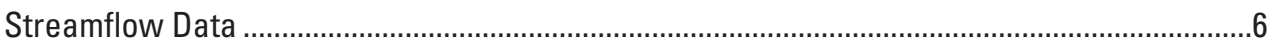

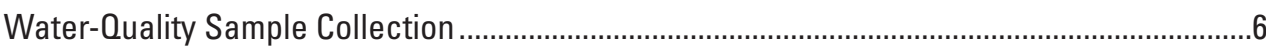

Annual Flow-Normalized Total Nitrogen and Total Phosophorus Concentrations at

Long-Term Sites ........................................................................................................

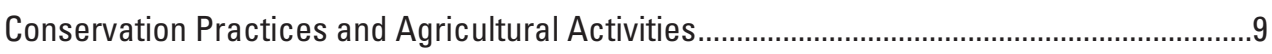

Conservation Reserve Program ..........................................................................

Nutrients From Commercial Fertilizer ...................................................................

Nutrients From Livestock Manure .............................................................................

Total Nitrogen and Total Phosphorus Concentrations at Mississippi River Basin Healthy

Watersheds Initiative Sites....................................................................................10

Flow-Adjusted Total Nitrogen and Total Phosphorus Concentrations.............................10

Monthly Mean and Annual Mean Flow-Weighted Total Nitrogen and Total Phosphorus Concentrations ...............................................................................10

Temporal Changes of Total Nitrogen and Total Phosphorus Concentrations With

Comparisons to Conservation Practices and Agricultural Activities ..................................13

Annual Flow-Normalized Total Nitrogen and Total Phosphorus Concentrations at Long-Term Sites ....................................................................................................13

Conservation Reserve Program Acres and Annual Flow-Normalized Total Nitrogen and Total Phosphorus Concentrations Comparisons …………………………………....15

Nutrients From Commercial Fertilizer and Annual Flow-Normalized Total Nitrogen and Total Phosphorus Concentrations Comparisons .........................................................15

Nutrients From Livestock Manure and Annual Flow-Normalized Total Nitrogen and Total

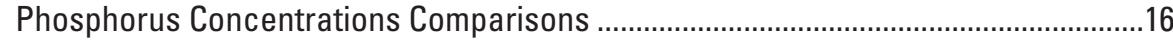

Total Nitrogen and Total Phosphorus Concentrations at MRBI Sites .......................................17

Flow-Adjusted Total Nitrogen and Total Phosphorus Sample Concentrations ...............17

Monthly Mean and Annual Mean Flow-Weighted Total Nitrogen and Total Phosphorus Concentrations .................................................................................

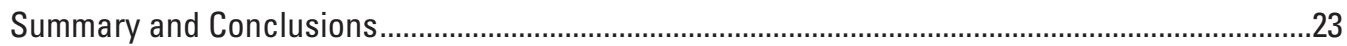

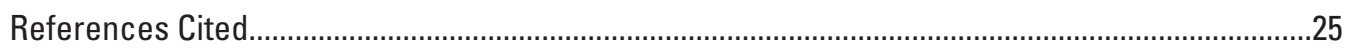

Appendixes 1-8. Supplemental Data for Selected Sites in Missouri and lowa (available for download at https://doi.org/10.3133/sir20175067...............................................................28 


\section{Figures}

1. Map showing locations of U.S. Geological Survey water-quality collection sites within the Lower Grand River, selected Missouri River tributary sites within or near the Lower Grand River, and Missouri River sites upstream and downstream from the confluence of the Grand River, Missouri and lowa.

2. Map showing land use of the Lower Grand River, including U.S. Geological Survey water-quality collection sites (sites 1-6 and 9), Missouri and lowa.

3. Graphs showing streamflow duration curves for selected long-term U.S. Geological Survey water-quality collection sites (sites 7-11; fig. 1; table 1) with daily mean streamflows for sample collection days, Missouri.

4. Graphs showing streamflow duration curves for 0 ctober 1, 2010, through September 30, 2015, at Mississippi River Basin Healthy Watersheds Initiative sites (sites 1-6; fig. 1; table 1) within the Lower Grand River, with daily mean streamflows for sample collection days, Missouri and lowa

5. Graphs showing annual flow-normalized total nitrogen and total phosphorus concentrations at five selected long-term sites (sites 7-11), Missouri..

6. Graphs showing ordinary least squares regression models at U.S. Geological Survey station 06902000 (site 9; fig. 1; table 1) with significant relations between flow-normalized total nitrogen and total phosphorus concentrations and nitrogen and phosphorus from commercial fertilizer

7. Graphs showing ordinary least squares regression models at U.S. Geological Survey station 06902000 (site 9; fig. 1; table 1) between flow-normalized total nitrogen and total phosphorus concentrations and total nitrogen and total phosphorus from total livestock manure.

8. Graphs showing ordinary least squares regression models at selected long-term sites (sites 7, 9, and 10; fig. 1; table 1) with significant relations between flow-normalized total nitrogen and total phosphorus concentrations and annual total metric tons of nitrogen and phosphorus from cattle manure

9. Graphs showing flow-adjusted total nitrogen concentrations for 0 ctober 1, 2010, through September 30, 2015, at six Mississippi River Basin Healthy Watershed Initiatives sites (sites 1-6; fig. 1; table 1) in the Lower Grand River, Missouri and lowa

10. Graphs showing flow-adjusted total phosphorus concentrations for October 1, 2010, through September 30, 2015, at six Mississippi River Basin Healthy Watershed Initiatives sites (sites 1-6; fig. 1; table 1) in the Lower Grand River, Missouri and lowa.

11. Graphs showing temporal changes in monthly mean and annual mean flow-weighted total nitrogen concentrations and monthly mean streamflow at six Mississippi River Basin Healthy Watersheds Initiative sites (sites 1-6; fig. 1; table 1) in the Lower Grand River, Missouri and lowa

12. Graphs showing temporal changes in monthly mean and annual mean flow-weighted total phosphorus concentrations and monthly mean streamflow at six Mississippi River Basin Healthy Watersheds Initiative sites (sites 1-6; fig. 1; table 1) in the Lower Grand River, Missouri and lowa 


\section{Tables}

1. Description of U.S. Geological Survey water-quality collection sites within the Lower Grand River, selected Missouri River tributary sites within or near the Lower Grand River, and Missouri River sites upstream and downstream from the confluence of the Grand River, Missouri and lowa .

2. Selected total nitrogen and total phosphorus model information for U.S. Geological Survey water-quality collection sites within the Lower Grand River, selected Missouri River tributary sites within or near the Lower Grand River, and Missouri River sites upstream and downstream from the confluence of the Grand River, Missouri and lowa

3. Results of ordinary least squares regression analyses between annual flow-normalized nitrogen and phosphorus concentrations and annual conservation practices and agricultural activities at three selected long-term sites within or near the Lower Grand River, Missouri and lowa

\section{Conversion Factors}

U.S. customary units to International System of Units

\begin{tabular}{lcl}
\hline \multicolumn{1}{c}{ Multiply } & By & \multicolumn{1}{c}{ To obtain } \\
\hline acre & Area & \\
acre & 4,047 & square meter $\left(\mathrm{m}^{2}\right)$ \\
acre & 0.4047 & hectare (ha) \\
acre & 0.4047 & square hectometer $\left(\mathrm{hm}^{2}\right)$ \\
square mile $\left(\mathrm{mi}^{2}\right)$ & 0.004047 & square kilometer $\left(\mathrm{km}^{2}\right)$ \\
& 2.590 & square kilometer $\left(\mathrm{km}^{2}\right)$ \\
\hline ounce, fluid $(\mathrm{fl.} \mathrm{oz})$ & Volume & \\
pint (pt) & 0.02957 & liter $(\mathrm{L})$ \\
quart (qt) & 0.4732 & liter $(\mathrm{L})$ \\
gallon (gal) & 0.9464 & liter $(\mathrm{L})$ \\
\hline & 3.785 & liter $(\mathrm{L})$ \\
\hline cubic foot per second $\left(\mathrm{ft}^{3} / \mathrm{s}\right)$ & Flow rate & \\
\hline
\end{tabular}




\section{Conversion Factors-Continued}

International System of Units to U.S. customary units

\begin{tabular}{lcl}
\hline \multicolumn{1}{c}{ Multiply } & By & \multicolumn{1}{c}{ To obtain } \\
\hline square meter $\left(\mathrm{m}^{2}\right)$ & Area & acre \\
hectare (ha) & 0.0002471 & acre \\
square hectometer $\left(\mathrm{hm}^{2}\right)$ & 2.471 & acre \\
square kilometer $\left(\mathrm{km}^{2}\right)$ & 2.471 & acre \\
square kilometer $\left(\mathrm{km}^{2}\right)$ & 247.1 & square mile $\left(\mathrm{mi}^{2}\right)$ \\
\hline & 0.3861 & \\
\hline liter $(\mathrm{L})$ & Volume & ounce, fluid $(\mathrm{fl} . \mathrm{oz})$ \\
liter $(\mathrm{L})$ & 33.81402 & pint $(\mathrm{pt})$ \\
liter $(\mathrm{L})$ & 2.113 & quart $(\mathrm{qt})$ \\
liter $(\mathrm{L})$ & 1.057 & gallon $(\mathrm{gal})$ \\
liter $(\mathrm{L})$ & 0.2642 & cubic inch $\left(\mathrm{in}{ }^{3}\right)$ \\
\hline & 61.02 & \\
\hline cubic meter per second $\left(\mathrm{m}^{3} / \mathrm{s}\right)$ & Flow rate & cubic foot per second $\left(\mathrm{ft}^{3} / \mathrm{s}\right)$ \\
\hline
\end{tabular}

\section{Datum}

Vertical coordinate information is referenced to the North American Vertical Datum of 1988 (NAVD 88).

Horizontal coordinate information is referenced to the North American Datum of 1983 (NAD 83).

Altitude, as used in this report, refers to distance above the vertical datum.

\section{Supplemental Information}

Concentrations of chemical constituents in water are given in milligrams per liter (mg/L). 


\section{Abbreviations}

$\begin{array}{ll}\text { CRP } & \text { Conservation Reserve Program } \\ \text { EPA } & \text { U.S. Environmental Protection Agency } \\ \text { FATN } & \text { flow-adjusted total nitrogen } \\ \text { FATP } & \text { flow-adjusted total phosphorus } \\ \text { FNTN } & \text { flow-normalized total nitrogen } \\ \text { FNTP } & \text { flow-normalized total phosphorus } \\ \text { FSA } & \text { Farm Service Agency } \\ \text { FWTN } & \text { flow-weighted total nitrogen } \\ \text { FWTP } & \text { flow-weighted total phosphorus } \\ \text { LOWESS } & \text { locally weighted scatterplot smoothing } \\ \text { MODNR } & \text { Missouri Department of Natural Resources } \\ \text { MRBI } & \text { Mississippi River Basin Healthy Watersheds Initiative } \\ \text { NRCS } & \text { Natural Resources Conservation Service } \\ \text { NWIS } & \text { National Water Information System } \\ \text { OLS } & \text { ordinary least squares } \\ p \text {-value } & \text { statistical probability } \\ r & \text { correlation coefficient } \\ R^{2} & \text { coefficient of determination } \\ \text { rloadest } & \text { U.S. Geological Survey Load Estimator program } \\ \text { STAC } & \text { Scientific and Technical Advisory Committee } \\ \text { TN } & \text { total nitrogen } \\ \text { TP } & \text { total phosphorus } \\ \text { USDA } & \text { U.S. Department of Agriculture } \\ \text { USGS } & \text { U.S. Geological Survey } \\ \text { WRTDS } & \text { Weighted Regressions on Time, Discharge, and Season } \\ & \end{array}$





\title{
Temporal Changes in Nitrogen and Phosphorus Concentrations with Comparisons to Conservation Practices and Agricultural Activities in the Lower Grand River, Missouri and lowa, and Selected Watersheds, 1969-2015
}

\author{
By Heather M. Krempa and Allison K. Flickinger
}

\begin{abstract}
This report presents the results of a cooperative study by the U.S. Geological Survey and Missouri Department of Natural Resources to estimate total nitrogen (TN) and total phosphorus (TP) concentrations at monitoring sites within and near the Lower Grand River hydrological unit. The primary objectives of the study were to quantify temporal changes in TN and TP concentrations and compare those concentrations to conservation practices and agricultural activities. Despite increases in funding during 2011-15 for conservation practices in the Lower Grand River from the Mississippi River Basin Healthy Watersheds Initiative, decreases in flow-normalized $\mathrm{TN}$ and TP concentrations during this time at the long-term Grand River site were less than at other long-term sites, which did not receive funding from the Mississippi River Basin Healthy Watersheds Initiative. The relative differences in the magnitude of flow-normalized TN and TP concentrations among long-term sites are directly related to the amount of agricultural land use within the watershed. Significant relations were determined between nitrogen from cattle manure and flow-normalized TN concentrations at selected long-term sites, indicating livestock manure may be a substantial source of nitrogen within the selected long-term site watersheds. Relations between flow-normalized TN and TP concentrations with Conservation Reserve Program acres and with nitrogen and phosphorus from commercial fertilizer indicate that changes in these factors alone did not have a substantial effect on stream TN and TP concentrations; other landscape activities, runoff, within-bank nutrients that are suspended during higher streamflows, or a combination of these have had a greater effect on stream TN and TP concentrations; or there is a lag time that is obscuring relations. Temporal changes in flow-adjusted TN and TP concentrations were not substantial at Lower Grand River Mississippi River Basin Healthy Watersheds Initiative sites, indicating factors besides stream variability did not have substantial effects on TN and
\end{abstract}

TP concentrations. Flow-weighted TN and TP concentrations at Lower Grand River Mississippi River Basin Healthy Watershed Initiative sites increase with increasing streamflow, which indicates runoff, within-bank nutrients that are suspended during higher streamflows, or both, have more effect on stream TN and TP concentrations than consistent point sources or groundwater sources. Timing of TN and TP concentration increases compared to streamflow increases indicate that nitrogen and phosphorus loads are more strongly related to streamflow than to a particular period of the year, indicating that runoff, within-bank nutrients that are suspended during higher streamflows, or both are a substantial source of nutrients regardless of timing.

\section{Introduction}

The effects of excess nutrients in the environment can be detrimental to stream and river quality. Elevated nitrogen and phosphorus concentrations in streams often lead to impairment that can degrade water use for drinking supply, irrigation, recreation, aquatic habitat, and tourism (Creekmore, 1999; Femmer, 2011). Elevated nutrients in streams can increase algal biomass, which can propagate impairment by decreasing light availability, creating a loss of habitat and biodiversity, depleting oxygen, and causing increased frequency of harmful algal blooms (Creekmore, 1999; Femmer, 2011; Rabalais and others, 2002). Increases in nitrogen and phosphorus in streams have been attributed to anthropogenic activities including use of fertilizers in agricultural areas, wastewater generation, and increased atmospheric deposition from the combustion of fossil fuels (Caraco and Cole, 1999; Creekmore, 1999; Howarth and others, 1996; Rabalais and others, 2002). The U.S. Environmental Protection Agency (EPA) has listed nutrients within the top five reported causes of impairment in assessed streams and rivers each year since the initial report was issued in 1992. The leading source of impairment to assessed streams 
and rivers consistently has been agriculture (EPA, variously dated [a]).

Agricultural conservation programs that are intended to protect or improve water quality, soil health, and wildlife habitat by taking agricultural land out of production or implementing conservation practices on working agricultural land have been in effect in the United States for at least 80 years (Claassen and others, 2008; Johansson and Cattaneo, 2006). Several agricultural conservation programs that have been or are currently (2016) available to agricultural producers in Missouri provide financial and technical support for conservation practices on agricultural land and are supported by the U.S. Department of Agriculture (USDA) Natural Resources Conservation Service (NRCS; NRCS, variously dated [b]) and the Missouri Department of Natural Resources (MODNR) Soil and Water Conservation Program (MODNR, variously dated). Also, the USDA Farm Service Agency (FSA) supports the Conservation Reserve Program (CRP), which pays an annual rental payment to landowners who take agricultural land out of production (FSA, variously dated $[\mathrm{b}]$ ). The main goals of these programs include improving soil, water, and air quality; improving wildlife and fish habitat; conserving water quantity; reducing soil erosion and sedimentation; restoring and enhancing critical wetlands; and protecting working agricultural lands by limiting nonagricultural uses of the land. Terrace systems with tile drainage, underground outlets, fence for livestock exclusion, nutrient management, grassed waterways, cover crop practices, and conservation crop rotation are a few of the many types of conservation practices supported by these programs.

In 2010, the USDA NRCS started a conservation landscape initiative known as the Mississippi River Basin Healthy Watersheds Initiative (MRBI; NRCS, variously dated [a]). The Mississippi River watershed was identified as a top priority for nutrient reductions by the USDA NRCS because of the dominantly agricultural land use, the associated harmful effects of nutrient loading on local water bodies, and the resulting annual midsummer northern Gulf of Mexico hypoxic zone or "dead zone" (Rabalais and others, 2002). This hypoxic zone is present when decomposition of organic matter, which is an oxygenconsuming process, outpaces oxygen diffusion, and warm summer surface waters allow for vertical stratification, which results in oxygen concentrations below critical thresholds for most living organisms in the lower stratified zone (Rabalais and others, 2002). The primary sources of organic matter in the northern Gulf of Mexico are driven by nutrient inputs, especially nitrogen, from the Mississippi River watershed (Rabalais and others, 2002), and nitrogen inputs are dominated by agricultural sources in the Mississippi River watershed (Howarth and others, 1996). The MRBI offers financial and technical assistance to agricultural producers in priority watersheds, including the Lower Grand River hydrologic unit (figs. 1, 2; hereafter referred to as the "Lower Grand River"), to implement voluntary conservation practices on working agricultural lands with the intention of solving local resource issues on individual participant's land and, in doing so, improving water quality locally and within the Mississippi River watershed.
The relation between water quality and landscape management practices, including implementation of conservation practices and intensity of agricultural activities (amount of fertilizer use and number of livestock within the watershed), is complex. Numerous concurrent conservation programs supporting a variety of practices make it difficult to determine the effectiveness of any one program or practice. Also, landscape management practices can have compounding or counteracting effects; for example, many conservation practices collectively may reduce stream nutrients, but an increase in fertilizer use or amount of manure from livestock may counteract nutrient reductions. Infield conservation practice benefits may be apparent including soil health improvements or gully erosion control; however, landscape management changes may take years, or even decades, to be detectable in water quality (Scientific and Technical Advisory Committee [STAC], 2013). Nutrients can be stored in groundwater and soils for decades (Van Meter and Basu, 2015); therefore, stream nutrient concentrations can reflect historical landscape practices regardless of current (2016) management practices.

Streamflow variability can greatly affect nutrient concentration changes, and removing the effects of streamflow variability from nutrient concentration changes allows the effects of landscape management changes, including conservation practices and agricultural activities, to be better assessed. If nutrient sources are dominated by surface runoff or within-bank nutrients that are suspended during higher streamflows, nutrient concentrations generally will increase with increasing streamflows; however, nutrient concentrations generally will decrease with increasing streamflows if nutrient sources are dominated by consistent point sources or groundwater contributions because inflows will have a diluting effect (Schertz and others, 1991; Langland and others, 2000). If the effects of streamflow variability on nutrient concentrations are not removed, it is difficult to discern the magnitude of nutrient concentration changes that are from landscape management changes. Nutrient concentration changes that are adjusted to remove the effects of streamflow variability represent the nutrient change in the absence of streamflow change, which makes it is possible to quantify nutrient concentration changes that are not caused by streamflow variations, allowing landscape management practices to be evaluated.

The focus of a cooperative study by the U.S. Geological Survey (USGS) and MODNR was to describe stream nutrient changes by using total nitrogen (TN) and total phosphorus (TP) concentrations that were adjusted to remove the effects of streamflow variability at selected sites within and near the Lower Grand River. The primary objectives of the study were to quantify long-term temporal changes in TN and TP concentrations and compare those concentrations among sites and to conservation practices and agricultural activities. Also, local stream TN and TP changes within the Lower Grand River that may be attributed to landscape management changes, including increases in conservation practices from the MRBI, were determined. 


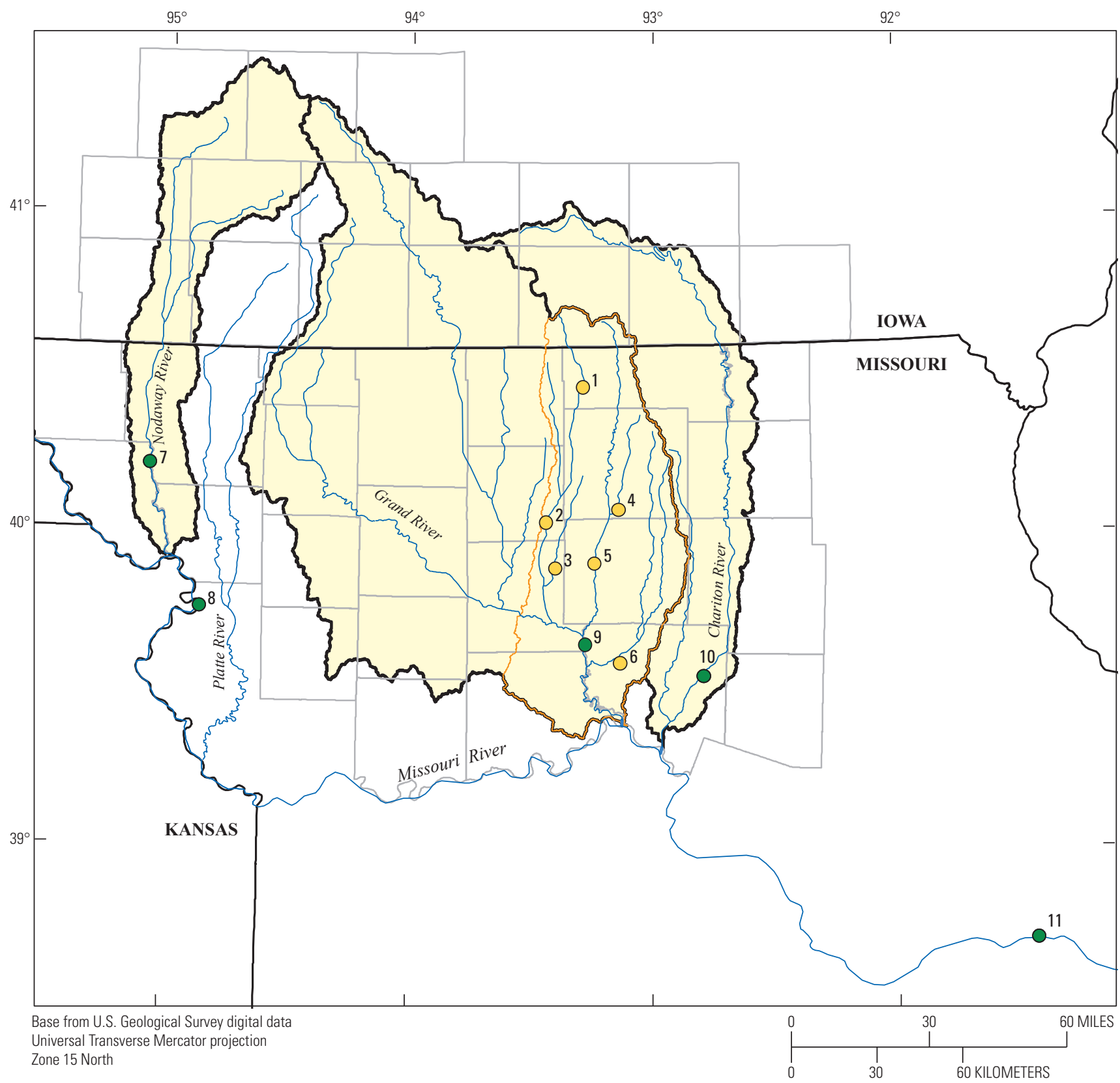

EXPLANATION

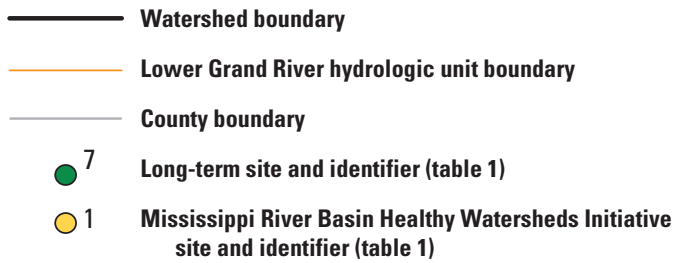

Figure 1. Locations of U.S. Geological Survey water-quality collection sites within the Lower Grand River, selected Missouri River tributary sites within or near the Lower Grand River, and Missouri River sites upstream and downstream from the confluence of the Grand River, Missouri and lowa. 


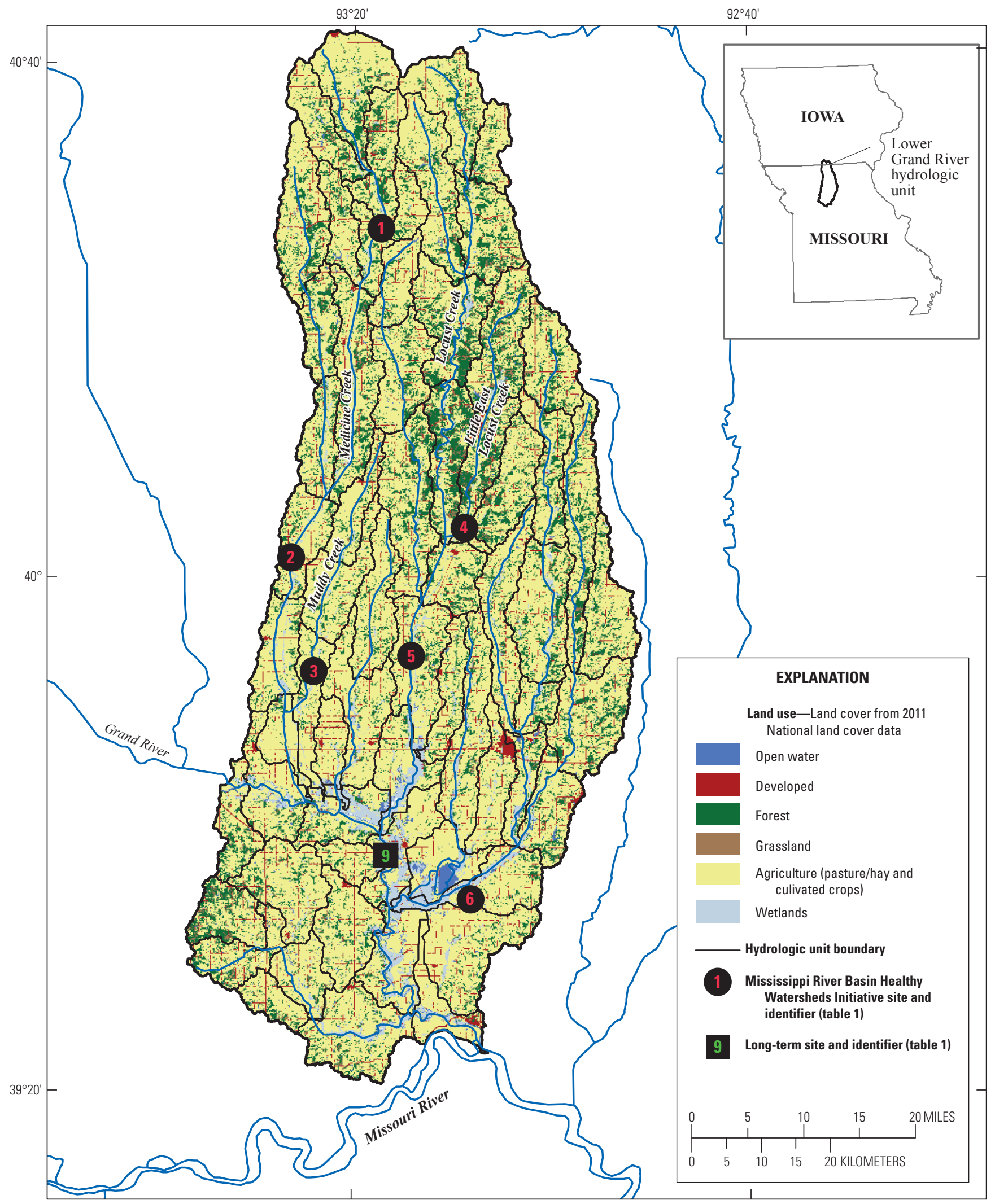

Base from U.S. Geological Survey digital data Universal

Transverse Mercator projection Zone 15 North

Figure 2. Land use of the Lower Grand River, including U.S. Geological Survey water-quality collection sites (sites 1-6 and 9), Missouri and lowa. 


\section{Purpose and Scope}

The purpose of this report is to present the results of the cooperative study by the USGS and MODNR on temporal changes in TN and TP concentrations in streams within and near the Lower Grand River (figs. 1, 2) and possible relations with conservation practices and agricultural activities. Temporal changes in TN and TP concentrations were adjusted to remove concentration variability caused by streamflow variability and long-term temporal TN and TP concentration changes were compared among sites and to conservation practices and agricultural activities, which include the annual amount of CRP acres, annual amount of nitrogen and phosphorus from commercial fertilizer, and annual amount of nitrogen and phosphorus from livestock manure within each watershed. This report focuses on TN and TP concentrations, in milligrams per liter $(\mathrm{mg} / \mathrm{L})$, to better understand the effects of landscape management changes on stream nutrients, as opposed to load values, which quantify total nutrients as the product of nutrient concentration and streamflow.

Annual flow-normalized TN and TP concentrations were determined using Weighted Regressions, on Time, Discharge, and Season (WRTDS; Hirsch and others, 2010) at five water-quality collection sites (USGS stations 06817700 , 06818000, 06902000, 06905500, and 06934500; sites 7, 8, 9, 10 , and 11; fig. 1; table 1) that were within or near the Lower Grand River and were part of a long-term (having 20 years or greater of periodic TN and TP concentration data and daily mean streamflow data) USGS cooperative program. Annual flow-normalized TN and TP concentrations were compared among long-term sites and to conservation practices and agricultural activities. In addition, flow-adjusted TN and TP concentrations were determined using model residuals relating streamflow and TN or TP concentrations, and monthly mean flow-weighted and annual mean flow-weighted TN and TP concentrations were determined using the USGS Load Estimator program (rloadest; Runkel and others, 2004) at six waterquality collection sites (USGS stations 06899900, 06900050, 06900640, 06901250, 06901500, and 06902995; sites 1, 2, 3, 4, 5, and 6; figs. 1, 2; table 1) within the Lower Grand River that were established for the MRBI during October or November 2010 .

Wilkison and Armstrong (2015) presented TN and TP concentrations from October 2010 through May 2014 for MRBI sites (sites 1-6) and from January 1990 through May 2014 for long-term sites (sites 7-11). This report extends the model periods used by Wilkison and Armstrong (2015) through the end of water year 2015 (September 2015) at all sites and extends the start of the model periods for long-term sites to the beginning of the earliest water year that TN or TP samples were collected during consecutive water years. A water year is the period from October 1 to September 30 and is designated by the year in which it ends.

Table 1 Description of U.S. Geological Survey water-quality collection sites within the Lower Grand River, selected Missouri River tributary sites within or near the Lower Grand River, and Missouri River sites upstream and downstream from the confluence of the Grand River, Missouri and lowa.

[ $\mathrm{km}^{2}$, square kilometer; agriculutral land cover, pasture/hay plus cultivated crops; MRBI, Mississippi River Basin Healthy Watersheds Inititive]

\begin{tabular}{|c|c|c|c|c|c|}
\hline $\begin{array}{c}\text { Site } \\
\text { identifier } \\
\text { (figs. 1, 2) }\end{array}$ & $\begin{array}{l}\text { U.S. Geological Survey } \\
\text { station name }\end{array}$ & $\begin{array}{l}\text { U.S. Geological Survey } \\
\text { station number }\end{array}$ & Site type & $\begin{array}{l}\text { Drainage area } \\
\qquad\left(\mathrm{km}^{2}\right)\end{array}$ & $\begin{array}{l}\text { Percentage } \\
\text { agricultural land } \\
\text { cover within } \\
\text { watershed }^{1}\end{array}$ \\
\hline 1 & Medicine Creek near Lucerne, Missouri & 06899900 & MRBI & 305 & 74 \\
\hline 3 & Muddy Creek near Chula, Missouri & 06900640 & MRBI & 187 & 84 \\
\hline 4 & Little East Locust Creek near Browning, Missouri & 06901250 & MRBI & 104 & 70 \\
\hline 5 & Locust Creek near Linneus, Missouri & 06901500 & MRBI & 1,435 & 69 \\
\hline 6 & Hickory Branch near Mendon, Missouri & 06902995 & MRBI & 36 & 88 \\
\hline 9 & Grand River near Sumner, Missouri & 06902000 & Long-term & 17,931 & 74 \\
\hline 10 & Chariton River near Prairie Hill, Missouri & 06905500 & Long-term & 4,970 & 63 \\
\hline 11 & Missouri River at Hermann, Missouri & 06934500 & Long-term & $1,353,300$ & 31 \\
\hline
\end{tabular}

${ }^{1}$ Homer and others (2015). 


\section{Description of Study Area}

The Lower Grand River, in Missouri and Iowa (figs. 1, 2), is the focus of this study because of increased funding for conservation practices and increased monitoring that was facilitated through the MRBI and its partners (NRCS, variously dated [a]). The intent of Federal, State, and local partners was that increasing conservation efforts would reduce nutrient and sediment export to surface waters while improving infield soil health. The Grand River is a tributary to the Missouri River (figs. 1,2), and agriculture is the primary land use within the Grand River watershed (table 1) and the Lower Grand River (fig. 2). Five existing sites (sites 7-11; fig. 1; table 1) that were part of a long-term (having 20 years or greater of periodic TN and TP concentration data and daily mean streamflow data) USGS cooperative program were selected to compare TN and TP concentrations among sites and to conservation practices and agricultural activities. Long-term sites include a site on the Grand River within the Lower Grand River (site 9), two additional Missouri River tributary sites (sites 7 and 10), and two Missouri River sites, one upstream (site 8) and one downstream (site 11) from the confluence of the Grand River (fig. 1; table 1). The primary land use within selected Missouri River tributary watersheds is agriculture (table 1); however, only the Lower Grand River was considered a priority area for the MRBI, which provided additional funding for NRCS conservation practices. There were no existing long-term sites on the Upper or Middle Grand River hydrological units; therefore, long-term TN and TP concentration changes at the site located on the Grand River within the Lower Grand River (site 9) represent the entire Grand River watershed (fig. 1). Six water-quality collection sites (MRBI sites 1-6; figs. 1, 2; table 1) were established on Lower Grand River tributaries in October or November 2010. The drainage areas of these sites range from 36 to 1,435 square kilometers $\left(\mathrm{km}^{2}\right.$; table 1$)$, and agriculture is the primary land use within each MRBI site (sites 1-6) watershed (69 to 88 percent; table 1; fig. 2).

\section{Study Methods}

Nitrogen and phosphorus concentrations from waterquality samples collected at sites within and near the Lower Grand River (figs. 1; table 1) and daily mean streamflows from streamgages were used to estimate TN and TP concentrations that were adjusted to remove concentration variability from streamflow variability. The variability in TN and TP concentrations caused by streamflow variability was removed using three different methods based on the duration of streamflow and water-quality data resulting in flow-normalized concentrations at long-term sites (sites 7-11; fig. 1; table 1) and flowadjusted, monthly mean, and annual mean concentrations at MRBI sites (sites 1-6; figs. 1, 2; table 1). Temporal changes in $\mathrm{TN}$ and TP concentrations were determined and long-term TN and TP concentration changes were compared to changes in conservation practices and agricultural activities.

\section{Streamflow Data}

USGS streamflow-gaging stations were established at water-quality collection sites to obtain streamflow data that were used in TN and TP concentration models. Stage data were collected every 15 minutes using nonsubmersible pressure transducers and uploaded to the USGS National Water Information System (NWIS) database (https://doi.org/10.5066/ F7P55KJN). Streamflow measurements routinely were made to develop and maintain a stage-streamflow relation for each site. This relation was used to compute streamflows from stage data. Daily mean streamflows were computed and stored in NWIS.

Because streamflow-gaging stations were established during October or November 2010 at MRBI sites (sites 1-6; figs. 1, 2; table 1), streamflow records for October 1 through November 10, 2010, at sites 1, 3, 4, and 6 were not complete, and missing daily mean values were estimated using ordinary least squares (OLS) regression models (appendix 1, available at https://doi.org/10.3133/sir20175067). Regression models were developed for the streamgages with missing data using logarithms of existing October and November 2010-15 daily streamflows at these sites as the dependent variables. Logarithms of existing October and November 2010-15 daily streamflows at site 5 were used as the independent variables. Also, streamgage malfunctions resulted in several additional missing daily streamflows at site 4 . Additional missing daily streamflows from gage malfunctions at site 4 were estimated using an OLS regression model between logarithms of daily mean streamflows for the entire streamflow record at sites 4 and 5 from October 1, 2010, through September 30, 2015 (appendix 1). A total of 4 percent of the streamflow record was estimated at site 4 .

\section{Water-Quality Sample Collection}

Water-quality samples were collected and processed using standard equal-width increment collection methods representative of the entire water column (USGS, variously dated) and analyzed at the USGS National Water Quality Laboratory according to published USGS laboratory methods in use during the time of sample collection and analysis (Fishman, 1993; Fishman and others, 1994; Patton and Kryskalla, 2003, 2011; Patton and Truitt, 1992, 2000; EPA, 1993). Concentrations of nitrate plus nitrite (dissolved or total), ammonia plus organic nitrogen, and total phosphorus were obtained from the USGS NWIS database (https://doi.org/10.5066/F7P55KJN; appendix 2, available at https://doi.org/10.3133/sir20175067). Total nitrogen was defined as the sum of nitrate plus nitrite (dissolved or total) and ammonia plus organic nitrogen, and only samples with concentrations for both constituents were used. Although samples were analyzed for various constituents, conservation practices focus on reductions in sediment and total nutrients, especially nitrogen and phosphorus; therefore, this report focuses on concentrations of TN and TP. 


\section{Annual Flow-Normalized Total Nitrogen and Total Phosophorus Concentrations at Long-Term Sites}

Annual flow-normalized total nitrogen (FNTN) and annual flow-normalized total phosphorus (FNTP) concentrations were estimated at long-term sites (sites 7-11; fig. 1; table 1) using Weighted Regressions, on Time, Discharge, and Season (WRTDS; Hirsch and others, 2010) from the start of the nitrogen and phosphorus model period (table 2) through September 2015 (appendix 3, available at https://doi. org/10.3133/sir20175067). The model periods and number of TN and TP samples used to develop the models varied among sites based on sample duration and frequency (table 2). The WRTDS model locally weights observations in the calibration dataset and builds separate regression models for each day, allowing coefficients to change over time (Sprague and others, $2009,2011)$. This dynamic coefficient approach is most appropriate for long-term surface water-quality datasets that have at least 20 years of data (Hirsch and others, 2010) including the long-term sites in this study. Concentrations that are reported as less than the laboratory reporting level are included in the model as a range of possible values. Flow-normalized TN and TP concentrations were estimated with WRTDS by assuming each daily mean streamflow on a single date during every year of the estimation period (for example, all January 1) were equally likely to happen; therefore, multiple daily concentrations were estimated for each day (each January 1 of each year) using every daily mean streamflow during each year within the estimation period for that particular date, while weighting calibration samples based on time, discharge, and season. The mean of all estimated concentrations for each day is the daily FNTN and FNTP concentration, and the mean of daily FNTN and FNTP concentrations for a water year (October 1 through September 30) is the annual FNTN and FNTP concentration (appendix 3).

The WRTDS model accuracy depends on several factors, and models cannot accurately estimate TN and TP concentrations throughout the range of streamflows unless calibration samples are collected throughout the range of streamflow conditions. The range of streamflows corresponding to waterquality sampling days was similar to the overall range of streamflows in the modeled periods (fig. 3). Model bias was computed for WRTDS TN and TP concentration models by comparing the sum of estimated concentrations on days when samples were collected to the sum of measured sample concentrations for each site, similar to methods described in Stenback and others (2011), and used in Garrett (2012), Sprague and others (2011), and Sprague and Gronberg (2013). The absolute bias in the nitrogen and phosphorus WRTDS models was not greater than 3.3 percent at any site (table 2).

Table 2. Selected total nitrogen and total phosphorus model information for U.S. Geological Survey water-quality collection sites within the Lower Grand River, selected Missouri River tributary sites within or near the Lower Grand River, and Missouri River sites upstream and downstream from the confluence of the Grand River, Missouri and lowa.

[rloadest, U.S. Geological Survey Load Estimator; WRTDS, Weighted Regressions on Time, Discharge, and Season; NA, not applicable]

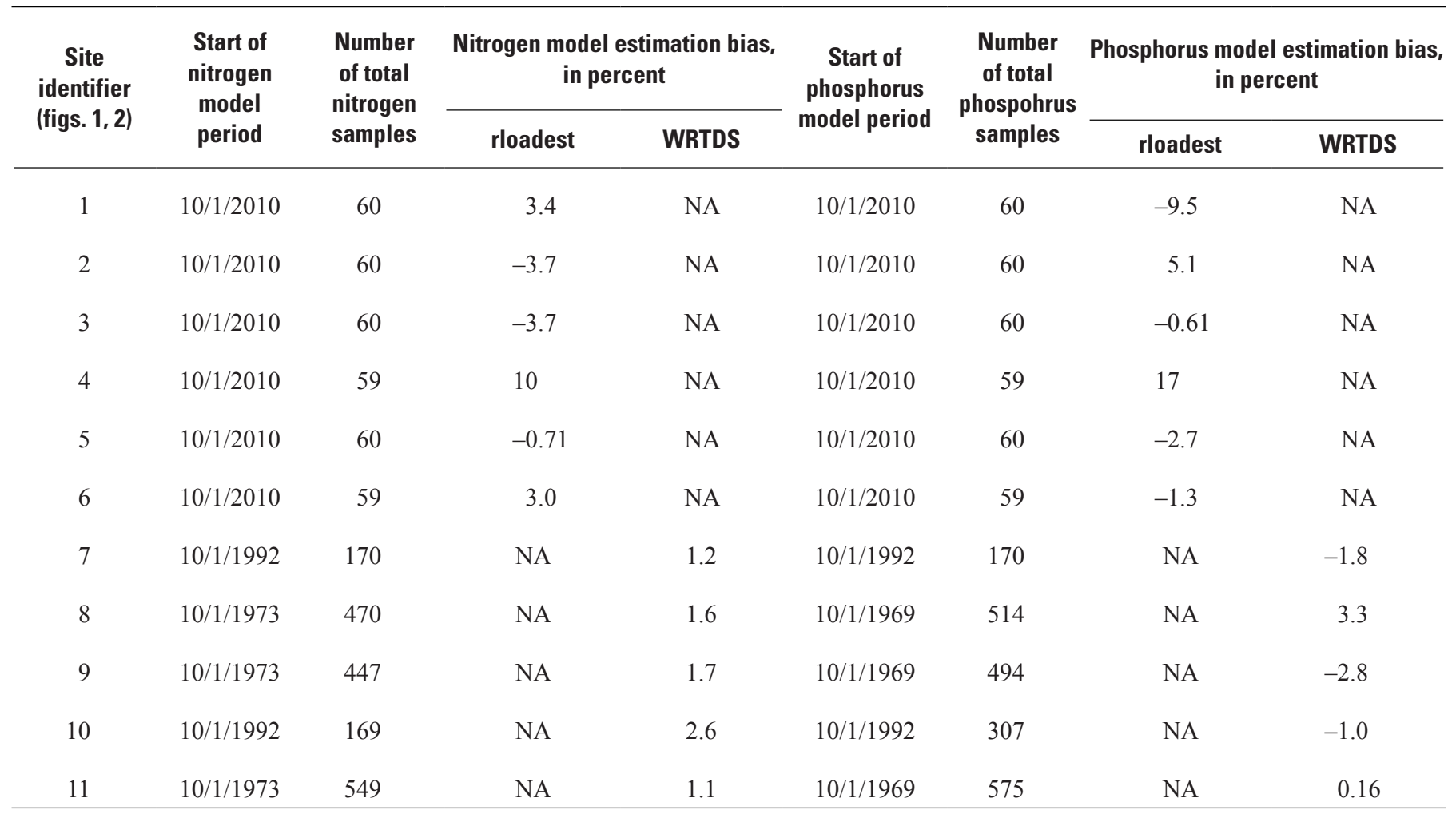



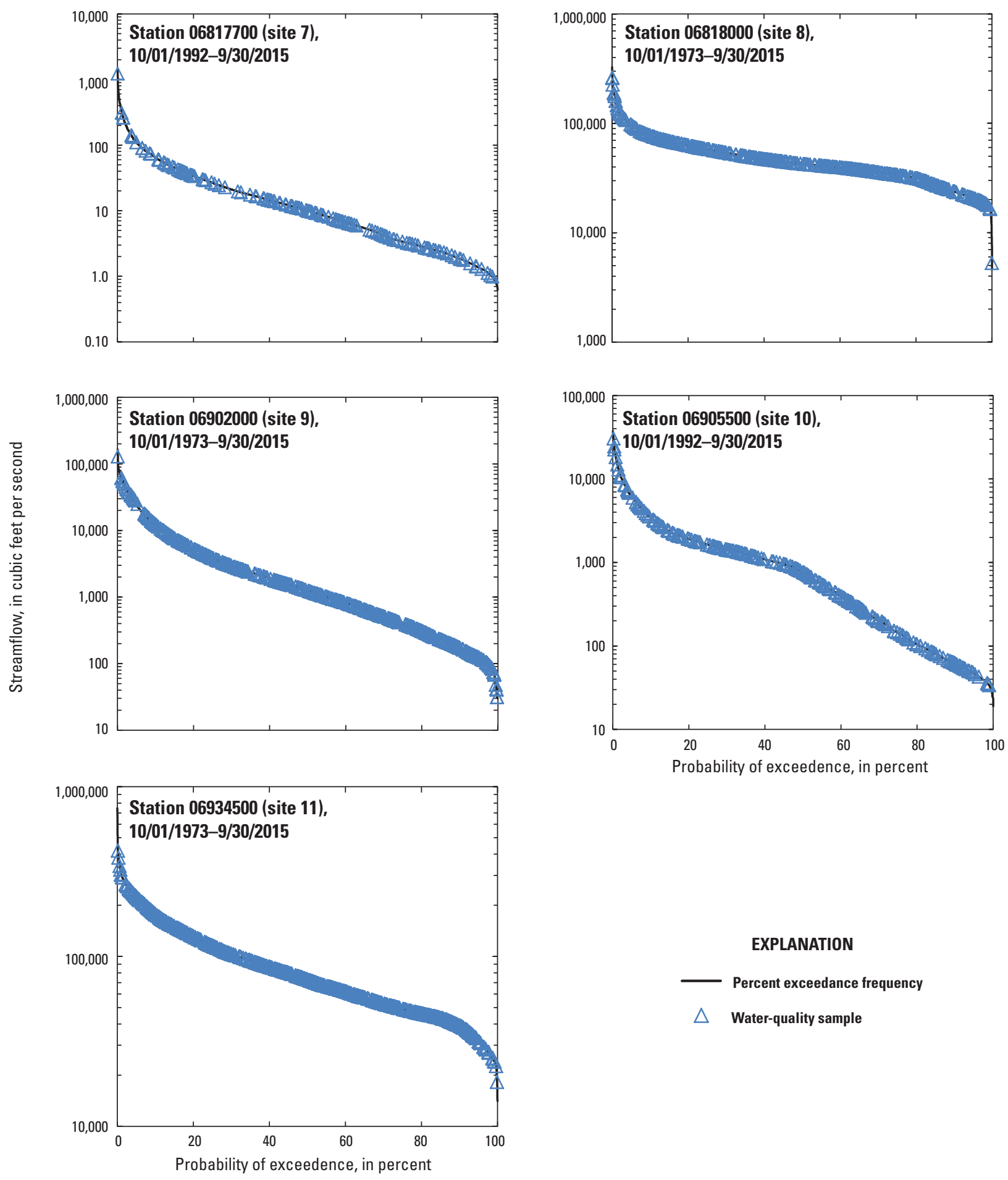

\section{EXPLANATION}

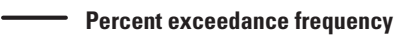

$\triangle$ Water-quality sample

Figure 3. Streamflow duration curves for selected long-term U.S. Geological Survey water-quality collection sites (sites 7-11; fig. 1; table 1) with daily mean streamflows for sample collection days, Missouri. 


\section{Conservation Practices and Agricultural Activities}

Long-term FNTN and FNTP concentrations were compared to CRP acres and agricultural activities at selected long-term sites (sites 7, 9, and 10; fig. 1; table 1). Agricultural activities include the annual amount of nitrogen and phosphorus from fertilizer and the annual amount of nitrogen and phosphorus from total livestock manure at site 9 and annual amount of nitrogen and phosphorus from cattle manure at selected long-term sites (sites 7, 9, and 10). Selected long-term sites include Missouri River tributary sites within and near the Lower Grand River that were included in this report (sites 7, 9, and 10). The MRBI sites and conservation practices supported by MODNR and NRCS did not have substantial data to be included in statistical analyses.

\section{Conservation Reserve Program}

The USDA FSA supports the CRP, which pays an annual rental payment to landowners who take agricultural land out of production (FSA, variously dated [b]), with the goal of improving environmental quality. Total acres enrolled in the CRP each year are publically available (FSA, variously dated [a]) for each county in the study area. Annual CRP acres for each county were multiplied by the percentage of the county within the watershed and summed to determine total annual CRP acres for the watersheds of each selected long-term site (sites 7, 9, and 10; fig. 1; table 1; appendix 4, available at https://doi.org/10.3133/sir20175067). The FNTN and FNTP concentrations at monitoring sites were used with CRP acres in OLS regression models to determine the amount of variability in FNTN and FNTP concentrations explained by CRP practices.

\section{Nutrients From Commercial Fertilizer}

Annual total metric tons of nitrogen and phosphorus from commercial fertilizer for selected watersheds with long-term sites (sites 7, 9, and 10; fig. 1; table 1) were used in OLS regression models with annual FNTN and FNTP concentrations. Total metric tons of imported nitrogen and phosphorus pentoxide $\left(\mathrm{P}_{2} \mathrm{O}_{5}\right)$ were available annually from 1974 through 2012 for Missouri (Missouri Agricultural Experimentation Station, variously dated), and the total metric tons of phosphorus was determined by multiplying total metric tons of phosphorus pentoxide by percent weight of phosphorus in phosphorus pentoxide (43.64 percent). Annual estimates of total metric tons of nitrogen and phosphorus from commercial fertilizer in Iowa were available from Gronberg and Spahr (2012) for 1987-2006. The average ratio between available (1987-2006) Iowa and Missouri total metric tons of nitrogen and phosphorus from commercial fertilizer was multiplied by annual Missouri values to determine total metric tons of Iowa commercial fertilizer before 1987 and after 2006. Missouri and Iowa counties and Statewide Iowa fertilizer expenses only were available about every 5 years (USDA, variously dated). Statewide Missouri fertilizer expenses were available annually (Missouri Agricultural Experimentation Station, variously dated). The ratios between county and Statewide commercial fertilizer expenses were used to estimate county total metric tons of nitrogen and phosphorus for Missouri counties for years that county commercial fertilizer expenses were available (about every 5 years). For years when county fertilizer expenses were not available, the total metric tons of nitrogen and phosphorus from imported commercial fertilizer were estimated using the average ratio of county and Statewide expenses for the previous year and following year that data were available. Annual county estimates of total metric tons of nitrogen and phosphorus from imported commercial fertilizer were multiplied by the percentage of the county within each watershed and summed to determine total metric tons of nitrogen and phosphorus from commercial fertilizer for the watersheds of each selected long-term site (sites 7, 9, and 10; fig. 1; table 1; appendix 4). The total metric tons of nitrogen and phosphorus from commercial fertilizer estimates (appendix 4) were used in conjunction with FNTN and FNTP concentrations (appendix 3) at selected long-term sites in OLS regression models to determine the amount of variability in FNTN and FNTP concentrations explained by commercial fertilizer nitrogen and phosphorus estimates.

\section{Nutrients From Livestock Manure}

In addition to fertilizer application, the production and delivery of livestock manure can have a substantial effect on nutrients in streams and rivers in agricultural areas.

Annual total metric tons of nitrogen and phosphorus from total livestock manure (cattle, chicken, hog, and sheep) were estimated for the Grand River (site 9; fig. 1; table 1; appendix 4) watershed and annual total metric tons of nitrogen and phosphorus from cattle manure were estimated for selected watersheds with long-term sites (sites 7, 9, and 10; fig. 1; table 1; appendix 4). The annual number of chickens, hogs, and sheep are reported about every 5 years and the annual number of cattle are reported almost annually (National Agricultural Statistics Service, variously dated). The annual numbers of livestock were multiplied by coefficients described in Goolsby and others (1999) and Ruddy and others (2006) for each livestock type to determine annual total metric tons of nitrogen and phosphorus from manure for each livestock type. Annual nitrogen and phosphorus estimates from total livestock manure for all livestock (cattle, chicken, hog, and sheep) were summed by county for years when all livestock types were reported (about every 5 years). Hog inventories at the county level were incomplete because of USDA reporting guidelines preventing the disclosure of individual operation data. Data from National Pollutant Discharge Elimination System permits (EPA, variously dated [b]) were used to estimate hog counts; however, data often were unavailable, which resulted in several years being underestimated. Since all livestock types 
were reported about every 5 years, and the TN and TP model periods began in 1993 for sites 7 and 10, there only were 4 years when concurrent annual nitrogen and phosphorus from total livestock manure and FNTN and FNTP concentrations were available. Nitrogen and phosphorus estimates from total livestock manure, therefore, only were used in OLS regression models for the Grand River (site 9) watershed, which had a longer TN and TP estimation period. Cattle manure was the greatest contributing source of annual nitrogen and phosphorus from livestock manure, representing 78 to 97 percent of annual nitrogen and 69 to 95 percent of annual phosphorus from total livestock manure, when available; therefore, the annual nitrogen and phosphorus estimates from cattle manure were used in OLS regression models to represent annual nitrogen and phosphorus from livestock manure. Annual county nitrogen and phosphorus from total livestock and from cattle manure were multiplied by the percentage of the county within the watershed and summed to determine total nitrogen and phosphorus from total livestock or cattle manure for watersheds with selected long-term sites (sites 7, 9, and 10; fig. 1; table 1) to determine the amount of variability in FNTN and FNTP concentrations explained by annual nitrogen and phosphorus from livestock manure.

\section{Total Nitrogen and Total Phosphorus Concentrations at Mississippi River Basin Healthy Watersheds Initiative Sites}

Two methods were used to quantify temporal TN and TP concentration changes at MRBI sites (sites 1-6; figs. 1, 2; table 1). The first method that is presented resulted in flowadjusted TN and TP concentrations. The second method that is presented resulted in flow-weighted monthly mean and flow-weighted annual mean TN and TP concentrations. Flowadjusted TN and TP concentrations were determined using the difference between measured sample TN and TP concentrations and those estimated using their relation with streamflow. Flow-weighted monthly mean and flow-weighted annual mean TN and TP concentrations were determined using the USGS Load Estimator program (rloadest), which uses streamflow (either a linear or quadratic relation) as a function, and other explanatory variables may include time (either linear or quadratic relation) and season (Runkel and others, 2004).

\section{Flow-Adjusted Total Nitrogen and Total Phosphorus Concentrations}

Flow-adjusted TN and TP concentrations are defined as the difference between measured sample TN and TP concentrations and those estimated using their relation with streamflow (Crawford and others, 1983; Heimann, and others, 2011; Rickert, 1985). Predicting TN and TP concentrations using the relation between streamflow and measured sample concentrations results in TN and TP concentration values that are estimated from streamflow alone, and the differences between the measured sample concentrations and the predicted concentrations (residuals) represent the TN and TP concentration change that is not explained by streamflow. If the relation between streamflow and TN and TP concentrations has not changed during the sampling period, the flow-adjusted concentrations would fluctuate randomly about zero. If the relation has changed, for example a new nutrient source was introduced or there were reductions in contributions from a source, it would be expected that the flow-adjusted concentrations would increase or decrease. A second-order polynomial regression model of logarithms of daily mean streamflows and logarithms of measured sample TN or TP concentrations was used to estimate TN and TP concentrations for each day that samples were collected at each MRBI site (sites 1-6; figs. 1, 2; table 1; appendixes 5, 6, available at https://doi.org/10.3133/ sir20175067). Visual inspection and the coefficient of determination $\left(R^{2}\right)$ indicated that using a second-order polynomial regression and a logarithm transformation provided a well fit relation between daily mean streamflows and measured sample TN and TP concentrations. Several TN values were reported as less than the laboratory reporting level resulting in censored values (NWIS TN remark; appendix 5). The relations between streamflows and TN concentrations were determined using the maximum and minimum values of censored concentrations. It was determined that censored TN concentrations did not substantially affect the flow-adjusted total nitrogen concentrations; therefore, the laboratory reporting level was used as a substitute for the censored values in regression models. The flow-adjusted total nitrogen (FATN) and flow-adjusted total phosphorus (FATP) concentrations were determined at each MRBI site for the period of October 2010 through September 2015, and were fitted with a locally weighted scatterplot smoothing (LOWESS; Cleveland and Devline, 1988) fit curve to qualitatively assess changes in FATN and FATP with time.

\section{Monthly Mean and Annual Mean Flow- Weighted Total Nitrogen and Total Phosphorus Concentrations}

Monthly mean and annual mean flow-weighted total nitrogen (FWTN) and flow-weighted total phosphorus (FWTP) concentrations were estimated using rloadest at each MRBI site (sites 1-6; figs. 1, 2; table 1) for the period of October 2010 through September 2015. The rloadest program uses constant coefficients through time, which may result in biased estimates if the relation between streamflow and TN and TP concentration is not consistent, a condition that is more likely in longer datasets. Since MRBI sites (sites 1-6) only have 5 years of data, the rloadest program was used. Models were selected separately for TN and TP concentrations for each MRBI site from several predefined models that are available in the rloadest program. Models were selected based on the statistical probability ( $p$-values) of variables, bias diagnostic values (Runkel and others, 2004), Akaike Information 
Criteria (Akaike, 1981), and the Nash-Sutcliffe efficiency (Nash and Sutcliffe, 1970) to optimize model fit without the use of unnecessarily complex models. Predefined models use streamflow (either a linear or quadratic relation) as a function, and other explanatory variables may include time (either linear or quadratic relation) and season (Runkel and others, 2004). Selected models were used to estimate daily TN and TP loads and the estimated loads were divided by daily mean streamflows to provide daily FWTN and FWTP concentrations. The rloadest program does not recognize concentrations that are censored at less than the laboratory reporting level as a range of values; therefore, daily FWTN and FWTP concentrations were determined using the maximum and minimum values of censored concentrations. There was not a substantial difference between results; therefore, the laboratory reporting level was used in rloadest to determine monthly mean and annual mean FWTN and FWTP concentrations. The mean of daily FWTN and FWTP concentrations for each month are monthly mean FWTN and monthly mean FWTP concentrations (appendix 7, available at https://doi.org/10.3133/sir20175067), and the mean of flow-weighted daily concentrations for each water year (October 1 through September 30) are annual mean FWTN and annual mean FWTP (appendix 8, available at https://doi.org/10.3133/sir20175067).

The accuracy of TN and TP estimation models, including rloadest, depend on several factors, and models cannot accurately estimate TN and TP concentrations throughout the range of streamflows unless calibration samples are collected throughout the range of streamflow conditions. The TN and TP samples were collected over the range of streamflows at all MRBI sites (sites 1-6) during the sampling period (fig. 4). Model bias was computed for rloadest TN and TP concentration models in the same manner as WRTDS model bias. The greatest absolute bias in rloadest nitrogen models was 10 percent at site 4 (table 2); absolute biases in nitrogen models were less than 4 percent at all other sites (table 2). Absolute biases in rloadest phosphorus models were 5.1 percent or less, except at site 1 (9.5 percent) and site 4 (17 percent; table 2) The total sums of the modeled TN and TP concentrations (rloadest TN and TP) and sampled TN and TP concentrations (NWIS TN

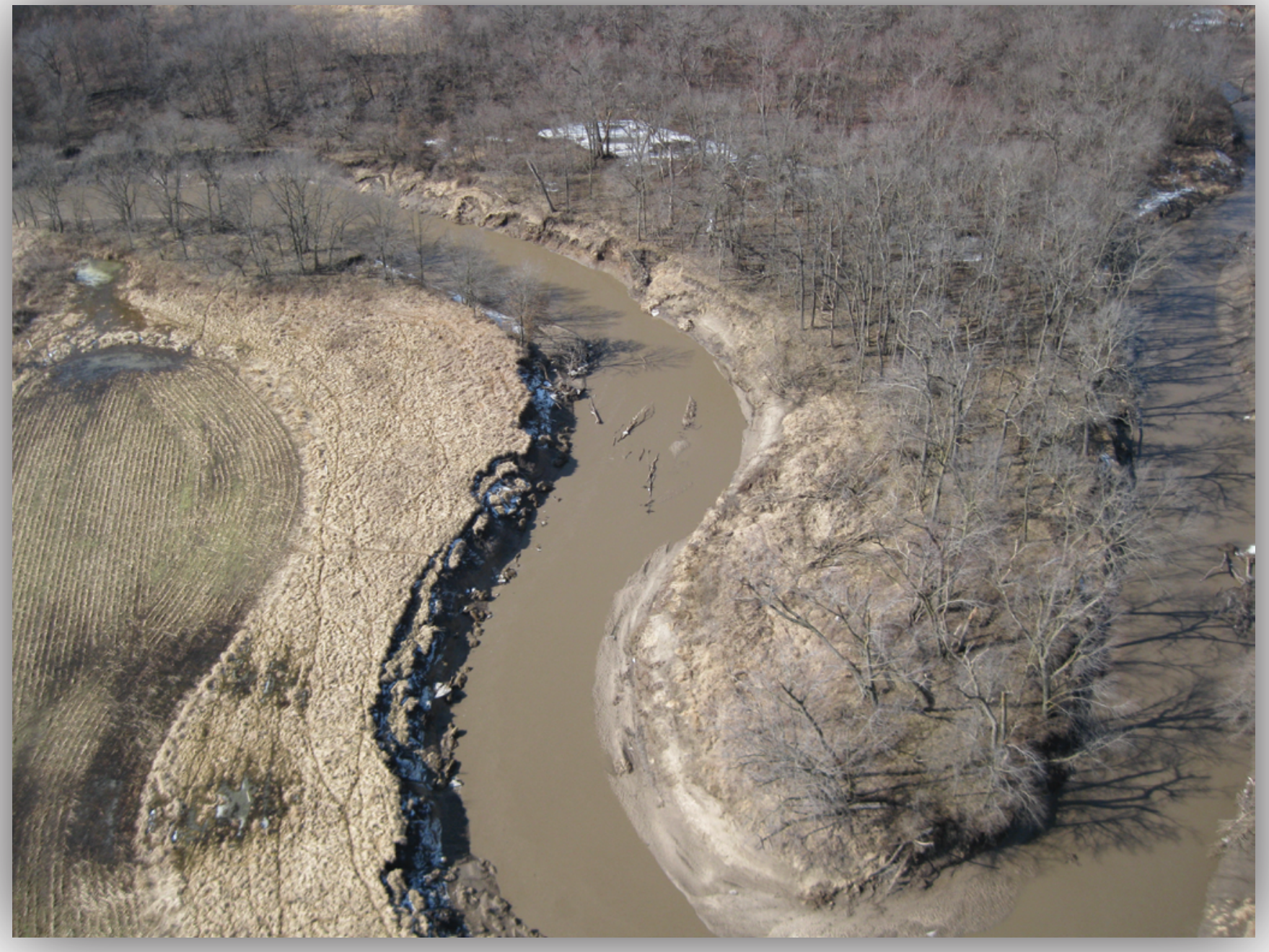

Photograph showing the Grand River from an aerial view, February 2016 (Photograph by Greg Pitchford, Missouri Department of Conservation). 

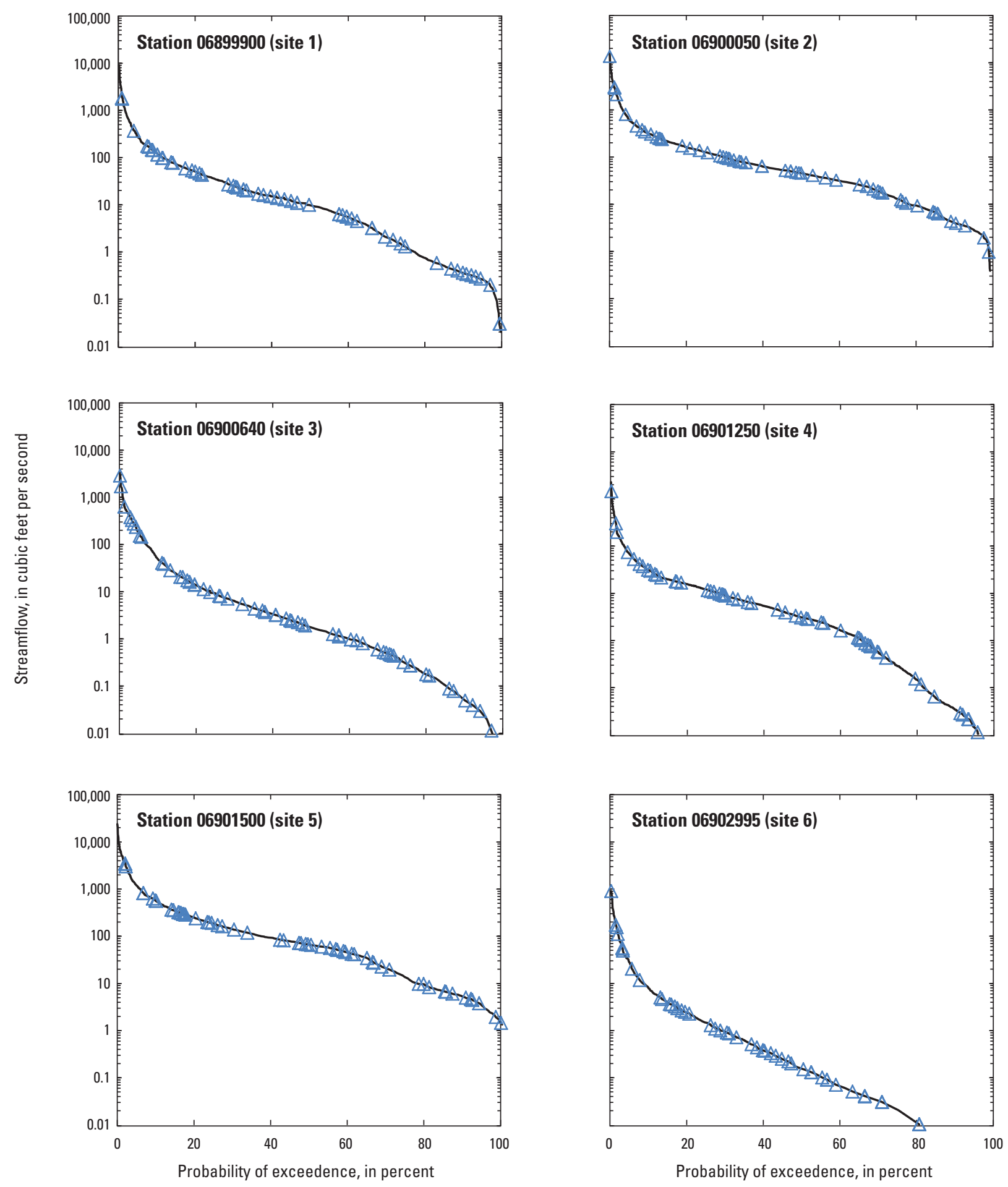

\section{EXPLANATION}

_ Percent exceedance frequency

$\triangle$ Water-quality sample

Figure 4. Streamflow duration curves for October 1, 2010, through September 30, 2015, at Mississippi River Basin Healthy Watersheds Initiative sites (sites 1-6; fig. 1; table 1) within the Lower Grand River, with daily mean streamflows for sample collection days, Missouri and lowa. 
and TP) at site 4 were about one-half the total sums at other sites (appendixes 5,6), which resulted in a greater percent difference. Model biases were considered acceptable to describe temporal changes in flow-weighted TN and TP concentrations.

\section{Temporal Changes of Total Nitrogen and Total Phosphorus Concentrations With Comparisons to Conservation Practices and Agricultural Activities}

Annual flow-normalized TN and TP concentrations were determined at long-term sites (sites 7-11; fig. 1; table 1) and flow-adjusted TN and TP concentrations and monthly mean and annual mean flow-weighted TN and TP concentrations were determined at MRBI sites (sites 1-6; figs. 1, 2; table 1). Annual flow-normalized TN and TP concentrations were compared to CRP acres, total metric tons of nitrogen and phosphorus from commercial fertilizer, and total metric tons of nitrogen and phosphorus from livestock. The MRBI sites and conservation practices supported by MODNR and NRCS did not have substantial data to be included in statistical analyses.

\section{Annual Flow-Normalized Total Nitrogen and Total Phosphorus Concentrations at Long-Term Sites}

Temporal changes in annual FNTN and FNTP concentrations generally were similar among long-term sites (sites 7-11), with increases and decreases occurring during similar periods (fig. 5); however, annual FNTN and FNTP concentrations, timing of inflection points (point at which the direction of the curve changes), and slopes (degree of change over time) of annual FNTN and FNTP concentration curves varied among sites. The TN and TP estimation periods for sites 7 and 10 did not begin until 1993 because of a lack of previous contiguous sample data. Overall, annual FNTN and FNTP concentrations decreased during the model period at site 8 ( 15 and 7.7 percent; fig. 5; appendix 3 ) and site 9 (34 and 4.9 percent). Increases in FNTN and FNTP concentrations were determined at site 7 (5.3 and 37 percent) and site 11 (7.1 and 31 percent) for the model period. Site 10 was the only site at which FNTN concentration decreased (20 percent) and FNTP concentrations increased (18 percent) during the model period (fig. 5; appendix 3). Both annual FNTN and FNTP concentrations have decreased at all long-term sites (sites 7-11) since water year 2008, with the exception of FNTP at site 11, which increased (fig. 5; appendix 3).

Despite increases in funding during 2011-15 for Lower Grand River conservation practices from the MRBI, decreases in annual FNTN and FNTP concentrations between water years 2011 and 2015 at site 9 (Grand River near Sumner, Missouri; fig. 1; table 1) were less than at other long-term sites (sites 7, 8, 10, and 11; fig. 5; appendix 3), which did not receive funding for conservation practices from the MRBI. The annual FNTN and FNTP concentrations decreased the least of any long-term site between water years 2011 and 2015 at site 9, with a 2.9 percent decrease in FNTN and a 3.0 percent decrease in FNTP. The greatest decreases in FNTN and FNTP concentrations were at site 8 , which is the upstream Missouri River site (fig. 1), with a 14 percent decrease in FNTN and 10 percent decrease in FNTP (appendix 3). The only determined FNTN and FNTP concentrations increases between water years 2011 and 2015 were in FNTP concentrations at site 11 (fig. 5; appendix 3).

There are several possible explanations why decreases in annual FNTN and FNTP concentrations were less at site 9 than other long-term sites (sites 7, 8, 10, and 11) despite increased funding for conservation practices from the MRBI. There is an unknown duration of time between implementation of land management changes and an observable change in stream TN and TP concentrations, known as lag time, which may be years or decades (Meals and Dressing, 2008; STAC, 2013; Van Meter and Basu, 2015). Lag times vary and depend on the type and extent of land management practices, soils, precipitation, hydrology, spatial distribution of practices relative to the stream, concentrations of nitrogen and phosphorus stored in soils and groundwater, and the morphometric characteristics of the watershed. If the lag time has not been exceeded, implemented conservation practices may have effects on stream TN and TP concentrations that are not observable at this time but could affect stream TN and TP concentrations in future years. Continued monitoring within these watersheds may provide a better understanding of how local lag times affect observable changes in stream TN and TP concentrations.

Also, the increases in the amount of conservation practices within the Lower Grand River may not have been substantial enough to reduce stream TN and TP concentrations in the entire Grand River watershed (fig. 1). There was an 89 percent increase in average monetary program allocations for NRCS supported conservation practices between the period before the MRBI (2006 through 2010) and those allocated during the MRBI period (2011 and 2015; Steven Hefner, NRCS, unpub. data, 2017). During the MRBI period, the payment amounts for each conservation practice remained comparable to payment amounts before the MRBI with the goal of increasing the amount of conservation practices without increasing payment amounts for each specific conservation practice. The entire Lower Grand River was authorized to offer MRBI supported conservation practices, but MRBI supported practices were implemented in only 42 of the 64 12-digit hydrologic unit code watershed areas, representing about 68 percent of the total Lower Grand River area; however, the entire area of each 12-digit hydrologic unit code watershed area would not have implemented conservation practices. The other longterm Missouri River tributary site watersheds (sites 7 and 10) did not receive increased funding through the MRBI but did have funding available through other programs to support conservation practices. Comparing the total watershed areas 


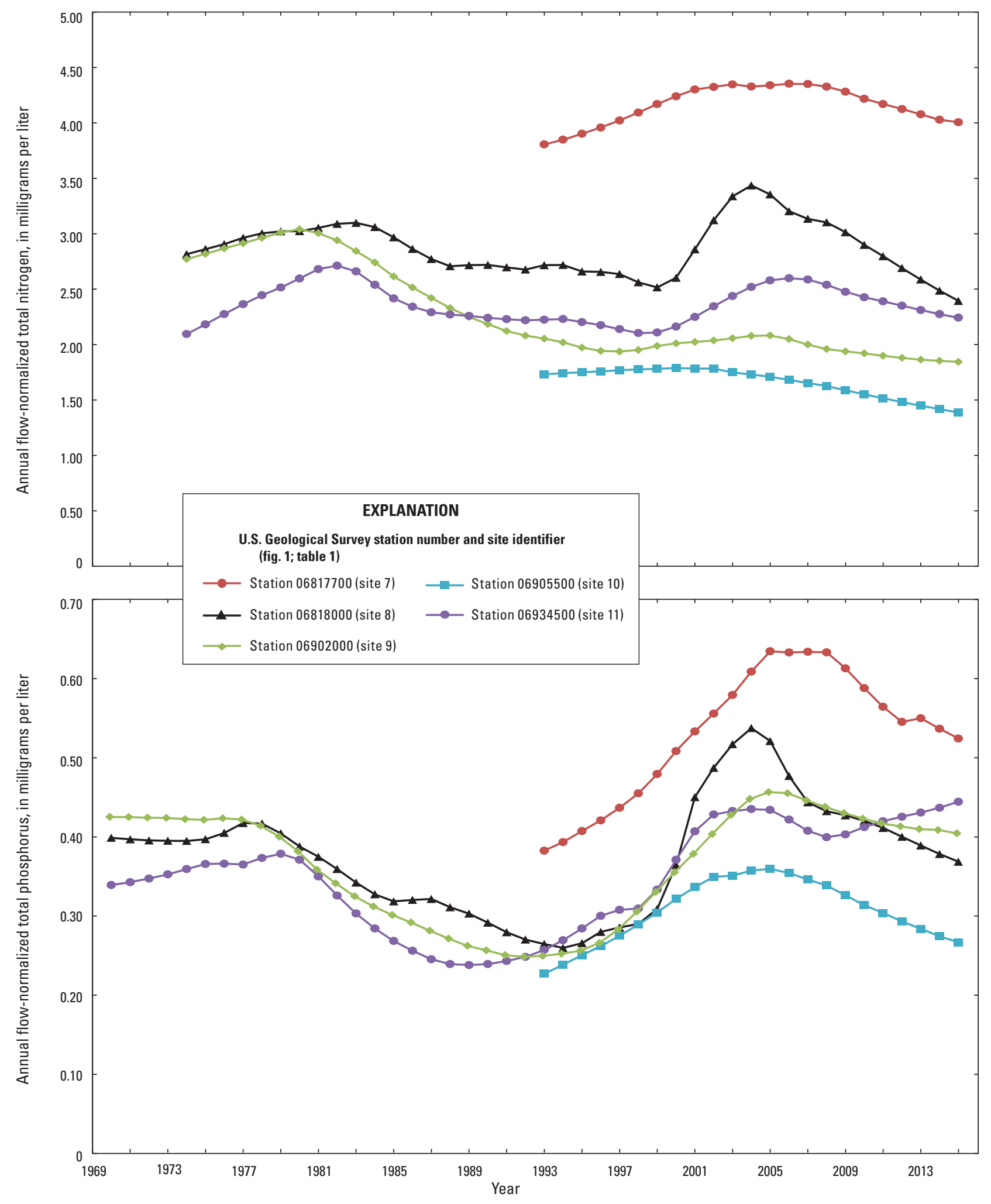

Figure 5. Annual flow-normalized total nitrogen and total phosphorus concentrations at five selected long-term sites (sites 7-11), Missouri. 
with conservation practices and total financial support among watersheds, regardless of funding sources, was out of the scope of the project but may provide insight as to why FNTN and FNTP concentration reductions were less at site 9 than other long-term Missouri River tributary sites (sites 7 and 10).

The specific types of conservation practices that were put into effect in the Lower Grand River during this period may not have a substantial effect on reducing nutrients. The MRBI program provides technical and financial assistance to land owners who volunteer to implement any of the many supported conservation practices on their agricultural land. The conservation practices that received the greatest NRCS financial support for the 2011 through 2015 period were terraces ("an earth embankment, or a combination ridge and channel, constructed across the field slope"; NRCS, variously dated [b]) followed by underground outlets ("a conduit or system of conduits installed beneath the surface of the ground to convey surface water to a suitable outlet"; NRCS, variously dated [b]). These conservation practices are most frequently implemented together and accounted for at least 50 percent of the financial support offered each year during 2011 through 2015. Interestingly, during 2007 through 2010 these practices accounted for only 25 percent or less of the total NRCS financial assistance.

The relative differences in the magnitude of flownormalized concentrations among selected long-term sites are directly related to the amount of agricultural land use in these watersheds. Annual FNTN and FNTP concentrations at selected long-term Missouri River tributary sites (sites 7, 9, and 10) consistently were highest at site 7 and lowest at site 10, with FNTN and FNTP concentrations at site 9 in between these two sites (fig. 5). Nodaway River (site 7) watershed has the highest percent of agricultural land use ( 85 percent) of the selected long-term Missouri River tributary sites, Chariton River (site 10) watershed has the lowest percentage of agricultural land use (63 percent) of the selected long-term Missouri River tributary sites, and the percentage of agricultural land use in the Grand River (site 9) watershed also is in between that of the Nodaway River and Chariton River (sites 7 and 10) watersheds ( 74 percent; table 1$)$.

Although, temporal changes in annual FNTN and FNTP concentrations at long-term sites were similar, the rate and magnitude of change and the timing of inflection points varied. This may indicate differences in the magnitude of conservation practice and agricultural activity changes, proximity of such changes in relation to streams, and variability in lag times between changes in conservation practices and agricultural activities and changes in stream TN and TP concentrations (differences in rate of delivery and transport). There are many conservation practices that may affect TN and TP concentrations including fence for livestock exclusion, nutrient management, grassed waterways, cover crop practices, and others. Agricultural activities that may affect TN and TP concentrations include fertilizer use, livestock manure amounts, and land uses that affect surface runoff rates.

\section{Conservation Reserve Program Acres and Annual Flow-Normalized Total Nitrogen and Total Phosphorus Concentrations Comparisons}

Relations between CRP acres and FNTN and FNTP concentrations were either not significant ( $p$-value greater than $[>]$ 0.05), not strong (absolute value of correlation coefficient $[r]$ less than $[<] 0.80$ ) when significant ( $p$-value $\leq 0.05$ ), or strong significant relations (absolute value of $r \geq 0.80$ and $p$-value $\leq 0.05$ ) were in the opposite direction than expected. A significant ( $p$-value $\leq 0.05$ ), inverse (negative $r$ ) relation was determined between annual CRP acres and FNTN concentrations for site 9; however, relations were not strong (absolute value of $r<0.80$; table 3 ). A significant ( $p$-value $\leq 0.05$ ) and strong (absolute value of $r \geq 0.80$ ) relation was determined between annual CRP acres and FNTN concentrations for site 10 (table 3 ); however, this relation was directly related (positive $r$ ), indicating that FNTN concentrations increased as CRP acres increased, which would not be expected. No strong (absolute value of $r \geq 0.80$ ), significant ( $p$-value $\leq 0.05$ ), inverse (negative $r$ ) relations were determined between annual CRP acres and annual FNTN and FNTP concentrations at any selected long-term site (sites 7, 9, and 10), which may indicate that changes in CRP acres alone have not had a substantial effect on stream TN and TP concentrations; other landscape activities, runoff, within-bank nutrients that are suspended during higher streamflows, or a combination of these have had a greater effect on stream TN and TP concentrations; or that the lag time between taking land out of production and observed reductions in stream TN and TP concentrations is substantial within these watersheds and obscures results.

\section{Nutrients From Commercial Fertilizer and Annual Flow-Normalized Total Nitrogen and Total Phosphorus Concentrations Comparisons}

There were no significant ( $\mathrm{p}$-value $\leq 0.05$ ), strong (absolute value of $r \geq 0.80$ ), and direct (positive $r$ ) relations between TN and TP from commercial fertilizer or annual FNTN and FNTP concentrations. Significant ( $p$-value $\leq 0.05$ ) relations were determined between annual nitrogen and phosphorus concentrations from commercial fertilizer and FNTN and FNTP concentrations for site 9 but were not strong (absolute value of $r<0.80$; table 3 ; fig. 6), and nitrogen from commercial fertilizer and FNTN were inversely related (negative $r$ ). It would be expected that $\mathrm{TN}$ and $\mathrm{TP}$ concentrations would increase with increases in commercial fertilizer, and an inverse relation would not be expected. Significant relations were not determined at other selected long-term sites (sites 7 and 10). The values used to estimate annual nitrogen and phosphorus from commercial fertilizer were amounts imported into the county and not amounts applied within the watershed, 
Table 3. Results of ordinary least squares regression analyses between annual flow-normalized nitrogen and phosphorus concentrations and annual conservation practices and agricultural activities at three selected long-term sites within or near the Lower Grand River, Missouri and lowa.

[ $p$-value, statistical probability; $r$, correlation coefficient; CRP, Conservation Reserve Program; bold values indicate a significiant ( $p$-value less than or equal to 0.05 ) or strong (absolute value of $r$ greater than or equal to 0.80 ) relation; --, not enough data available for analysis]

\begin{tabular}{|c|c|c|c|c|c|c|c|c|c|c|c|c|}
\hline \multirow{2}{*}{$\begin{array}{l}\text { Conservation } \\
\text { practice or } \\
\text { agricultural } \\
\text { activity }\end{array}$} & \multicolumn{6}{|c|}{ Nitrogen } & \multicolumn{6}{|c|}{ Phosphorus } \\
\hline & $p$-value & $r$ & $p$-value & $r$ & $p$-value & $r$ & $p$-value & $r$ & $p$-value & $r$ & $p$-value & $\mathbf{r}$ \\
\hline $\begin{array}{l}\text { Nutrient from com- } \\
\text { mercial fertilizer }\end{array}$ & 0.7 & 0.08 & $<0.01$ & -0.5 & 0.5 & -0.2 & 0.7 & -0.1 & $<0.01$ & 0.5 & 0.5 & 0.2 \\
\hline $\begin{array}{l}\text { Nutrient from total } \\
\text { livestock manure }\end{array}$ & -- & -- & $<0.01$ & 0.9 & -- & -- & -- & -- & 0.3 & 0.4 & -- & -- \\
\hline
\end{tabular}
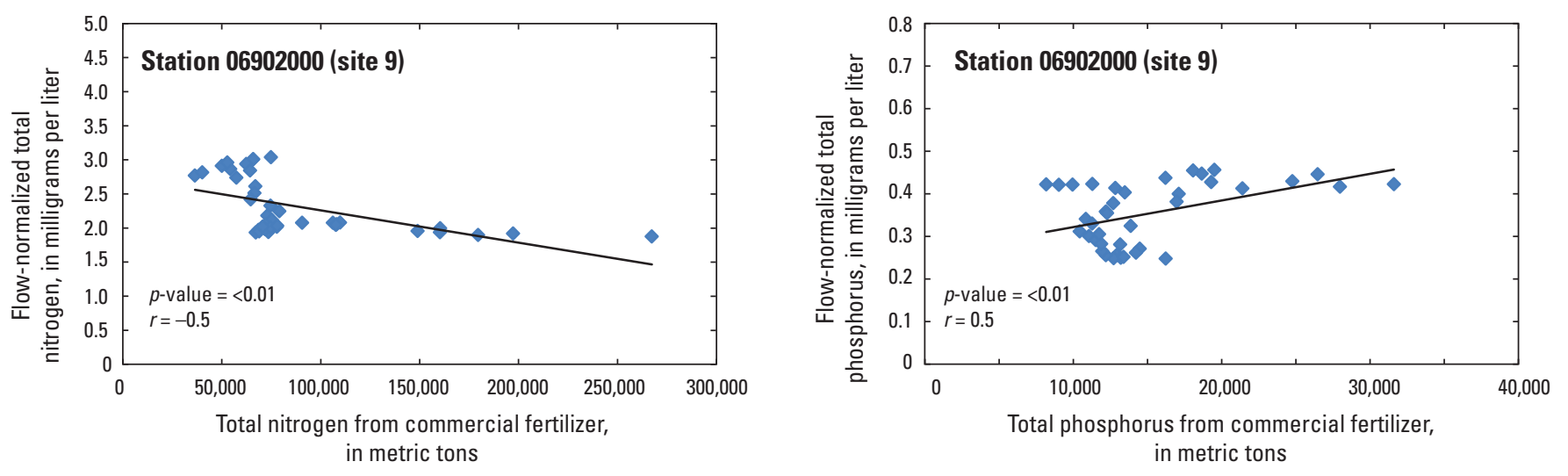

Figure 6. Ordinary least squares regression models at U.S. Geological Survey station 06902000 (site 9; fig. 1; table 1) with significant relations between flow-normalized total nitrogen and total phosphorus concentrations and nitrogen and phosphorus from commercial fertilizer. [ $p$-value, statistical probabillity; $r$, correlation coefficient]

total metric tons of fertilizer were extrapolated from expense data when amounts of imported fertilizer were not available, fertilizer expense data were extrapolated between years when annual expenses were unavailable, and watershed area data were extrapolated from county data, which could have resulted in TN and TP estimates from commercial fertilizer that were not representative of the watershed. These results indicate that changes in annual nitrogen and phosphorus from commercial fertilizer alone within these watersheds are not strongly (absolute value of $r<0.80$ ) correlated with changes in FNTN and FNTP concentrations at these sites or that the methods used to estimate annual nitrogen and phosphorus from commercial fertilizer for each watershed were not representative of the amount of commercial fertilizer applied within the watershed.

\section{Nutrients From Livestock Manure and Annual Flow-Normalized Total Nitrogen and Total Phosphorus Concentrations Comparisons}

A significant ( $\mathrm{p}$-value $\leq 0.05$ ) and strong (absolute value of $r \geq 0.80$ ) direct (positive $r$ ) relation was determined between nitrogen concentrations from total livestock manure and FNTN concentrations at site 9 (fig. 7; table 3) but not between phosphorus concentrations from total livestock manure and 

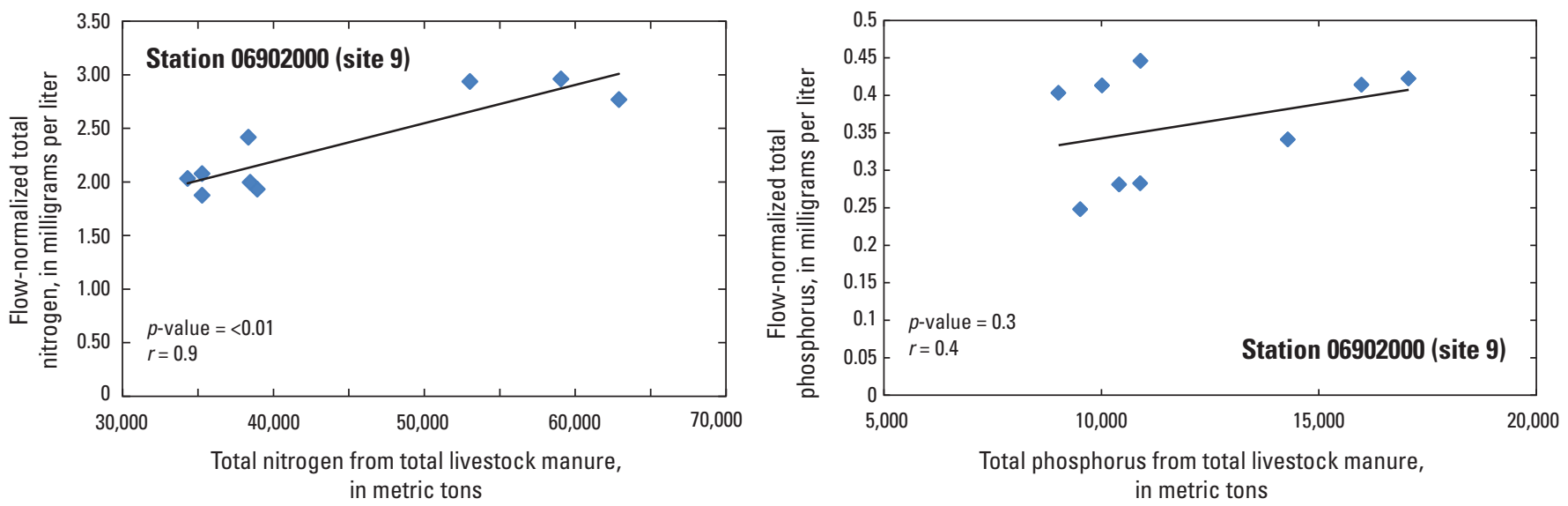

Figure 7. Ordinary least squares regression models at U.S. Geological Survey station 06902000 (site 9; fig. 1; table 1) between flownormalized total nitrogen and total phosphorus concentrations and total nitrogen and total phosphorus from total livestock manure. [ $p$-value, statistical probabillity; $r$, correlation coefficient]

FNTP concentrations. Site 9 was the only site that had substantial data for regression analyses between TN and TP from total livestock manure and FNTN and FNTP concentrations.

Significant ( $p$-value $\leq 0.05$ ), direct (positive $r$ ) relations were determined between nitrogen from cattle manure and FNTN concentrations at all selected long-term sites (sites 7, 9 , and 10), and relations were strong (absolute value of $r \geq 0.80$ ) for sites 9 and 10 (table 3; fig. 8). The only significant $(p$-value $\leq 0.05)$ relation between phosphorus from cattle manure and FNTP concentrations was for site 10, but relations were not strong (absolute value of $r<0.80$; table 3; fig. 8).

These results indicate that TN and TP from livestock manure have a greater effect on nitrogen concentrations than phosphorus concentrations, and livestock manure may be a substantial source of stream nitrogen especially within the Grand River and Chariton River (sites 9 and 10) watersheds. Identifying substantial nitrogen and phosphorus sources provides valuable information that can be used to target specific agricultural conservation practices that may have the most effect on stream TN and TP concentrations.

\section{Total Nitrogen and Total Phosphorus Concentrations at MRBI Sites}

Increases in flow-adjusted TN and TP concentrations (FATN and FATP) and annual mean flow-weighted TN and TP concentrations (FWTN and FWTP) between October 2010 and September 2015 were determined at some MRBI sites (sites 1-6) but were not substantial (figs. 9, 10, 11, 12). Monthly mean FWTN and FWTP concentrations followed general streamflow patterns with FWTN and FWTP concentrations increasing with increased streamflow, indicating runoff, within-bank nutrients that are mobilized during higher streamflows, or both are major sources of nitrogen and phosphorus inputs and have more effect on stream TN and TP concentrations than consistent point sources or groundwater sources.

\section{Flow-Adjusted Total Nitrogen and Total Phosphorus Sample Concentrations}

Temporal changes in FATN and FATP (figs. 9, 10) concentrations were displayed at some MRBI sites (sites 1-6) but were not substantial. Slight overall increases in FATN concentrations were displayed at sites 2, 3, and 6 (fig. 9). Increases in FATN concentrations followed by a decrease resulted in little overall change at sites 1,4 , and 5 (fig. 9).

Overall, increases in FATP concentrations were displayed at sites 3,5 , and 6 but were not substantial (fig. 10). There was little change in FATP concentrations at sites 1, 2, and 4. The lack of substantial temporal change in FATN and FATP at MRBI sites (sites 1-6) during the sample period indicates factors besides streamflow variability did not have a substantial effect on sample TN and TP concentration changes at these sites.

\section{Monthly Mean and Annual Mean Flow- Weighted Total Nitrogen and Total Phosphorus Concentrations}

Temporal changes in monthly mean FWTN and FWTP concentrations generally follow streamflow with FWTN and FWTP concentrations increasing with streamflow increases (figs. 11, 12), indicating runoff, within-bank nutrients that are suspended during higher streamflows, or both are major sources of nitrogen and phosphorus inputs and have more effect on stream TN and TP concentrations than consistent point sources or groundwater sources. 

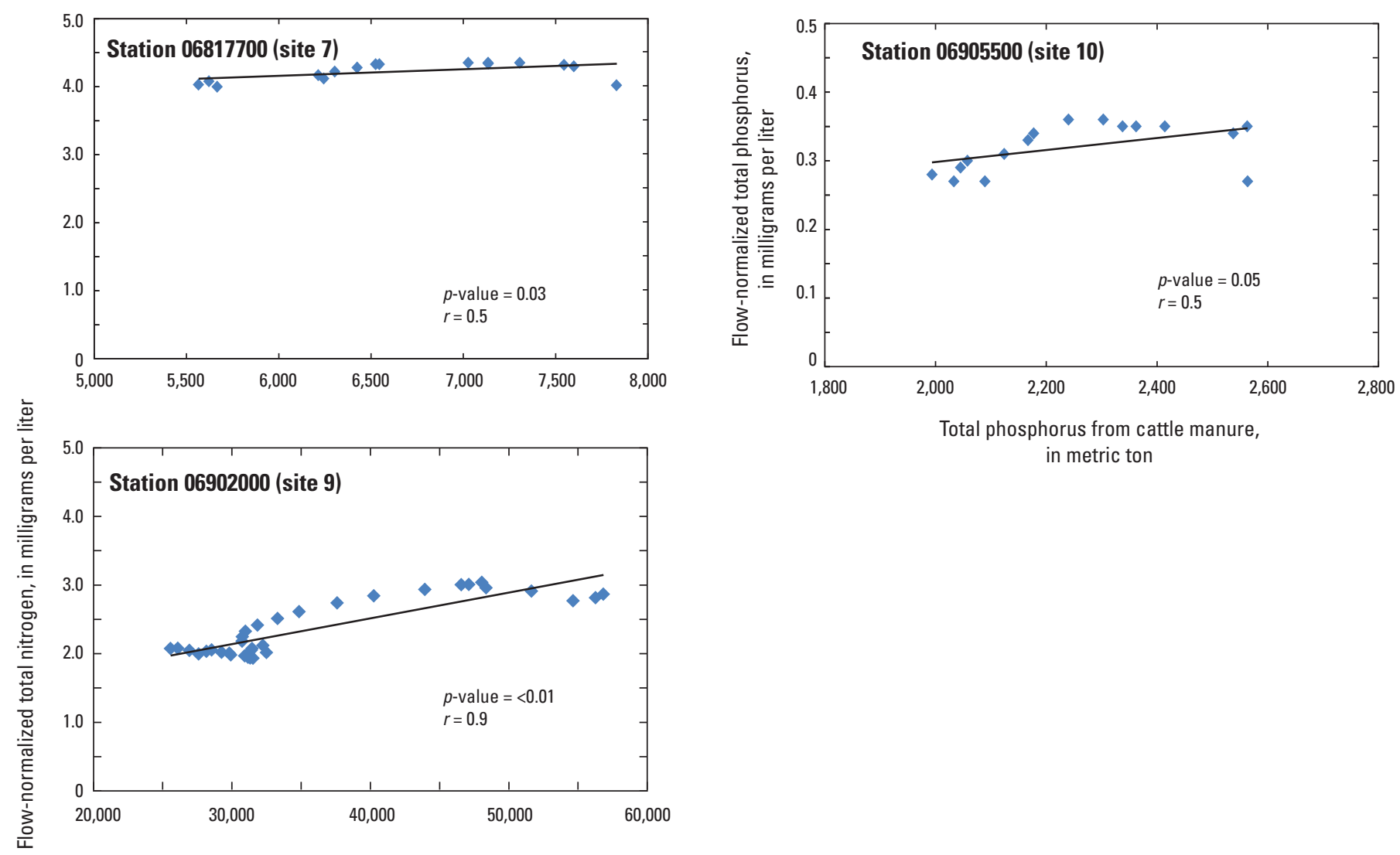

in metric ton

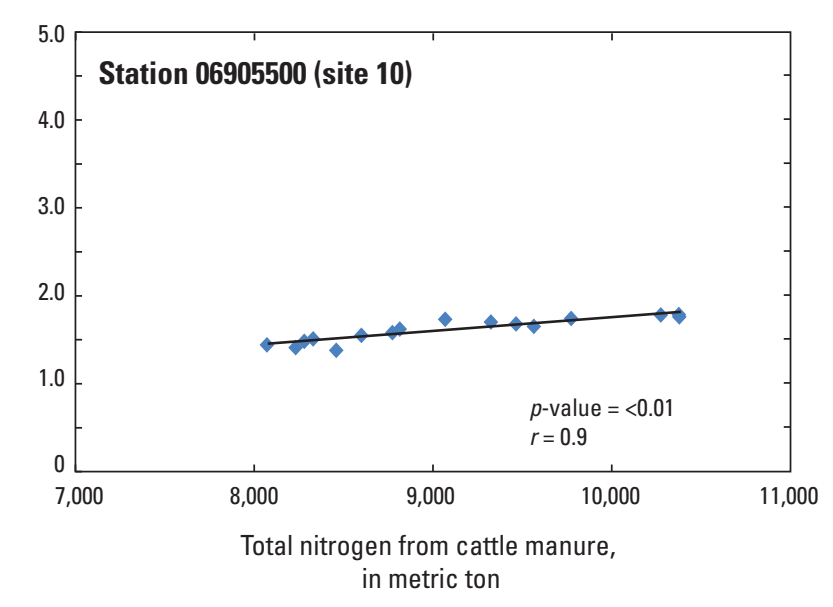

Figure 8. Ordinary least squares regression models at selected long-term sites (sites 7, 9, and 10; fig. 1; table 1) with significant relations between flow-normalized total nitrogen and total phosphorus concentrations and annual total metric tons of nitrogen and phosphorus from cattle manure. [ $p$-value, statistical probabillity; $r$, correlation coefficient] 

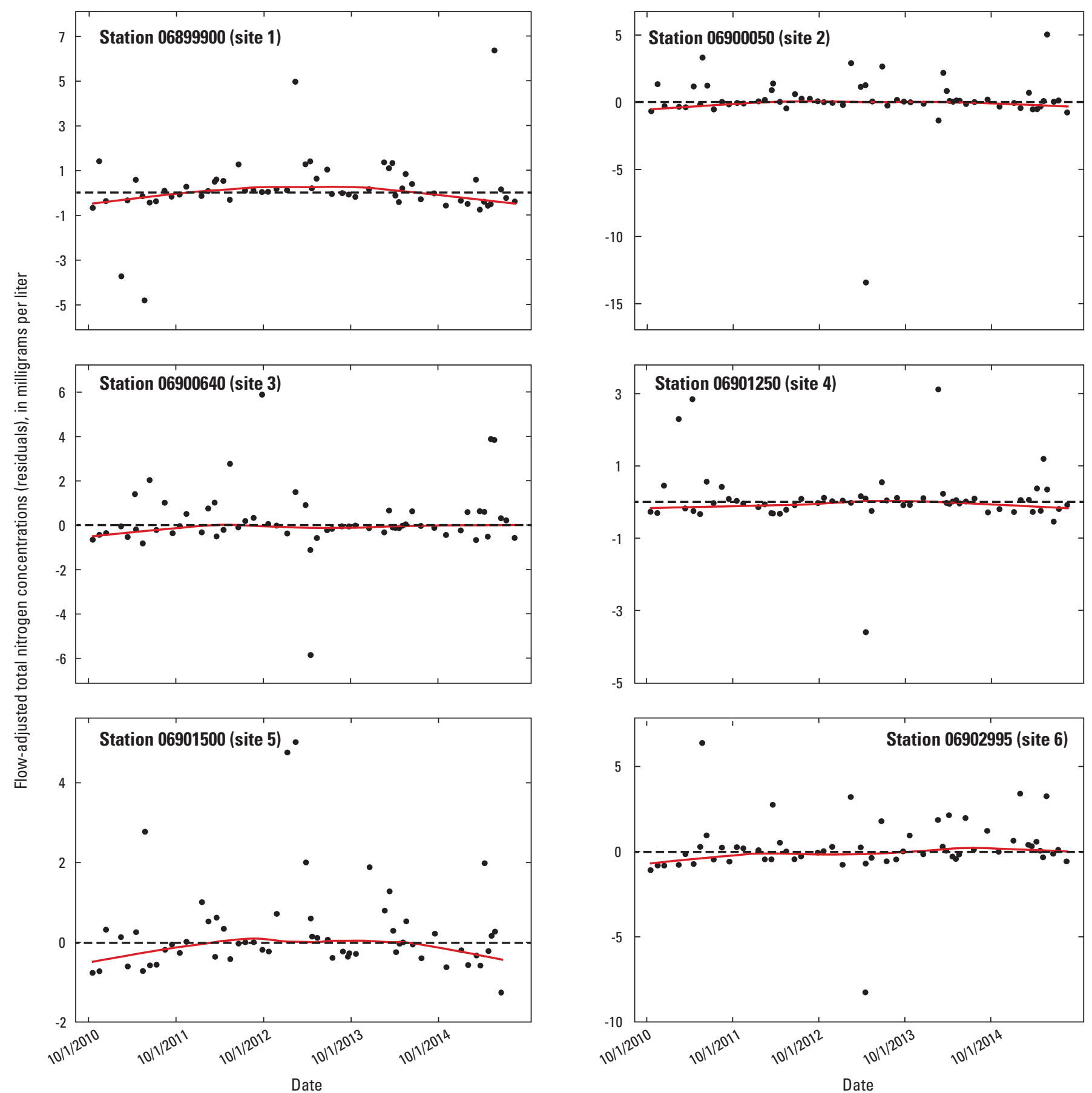

\section{EXPLANATION}

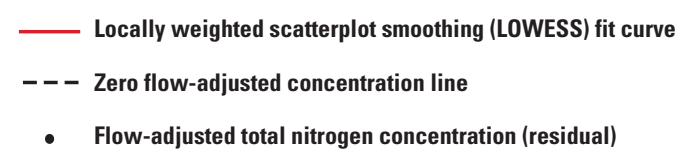

Figure 9. Flow-adjusted total nitrogen concentrations for October 1, 2010, through September 30, 2015, at six Mississippi River Basin Healthy Watershed Initiatives sites (sites 1-6; fig. 1; table 1) in the Lower Grand River, Missouri and lowa. 

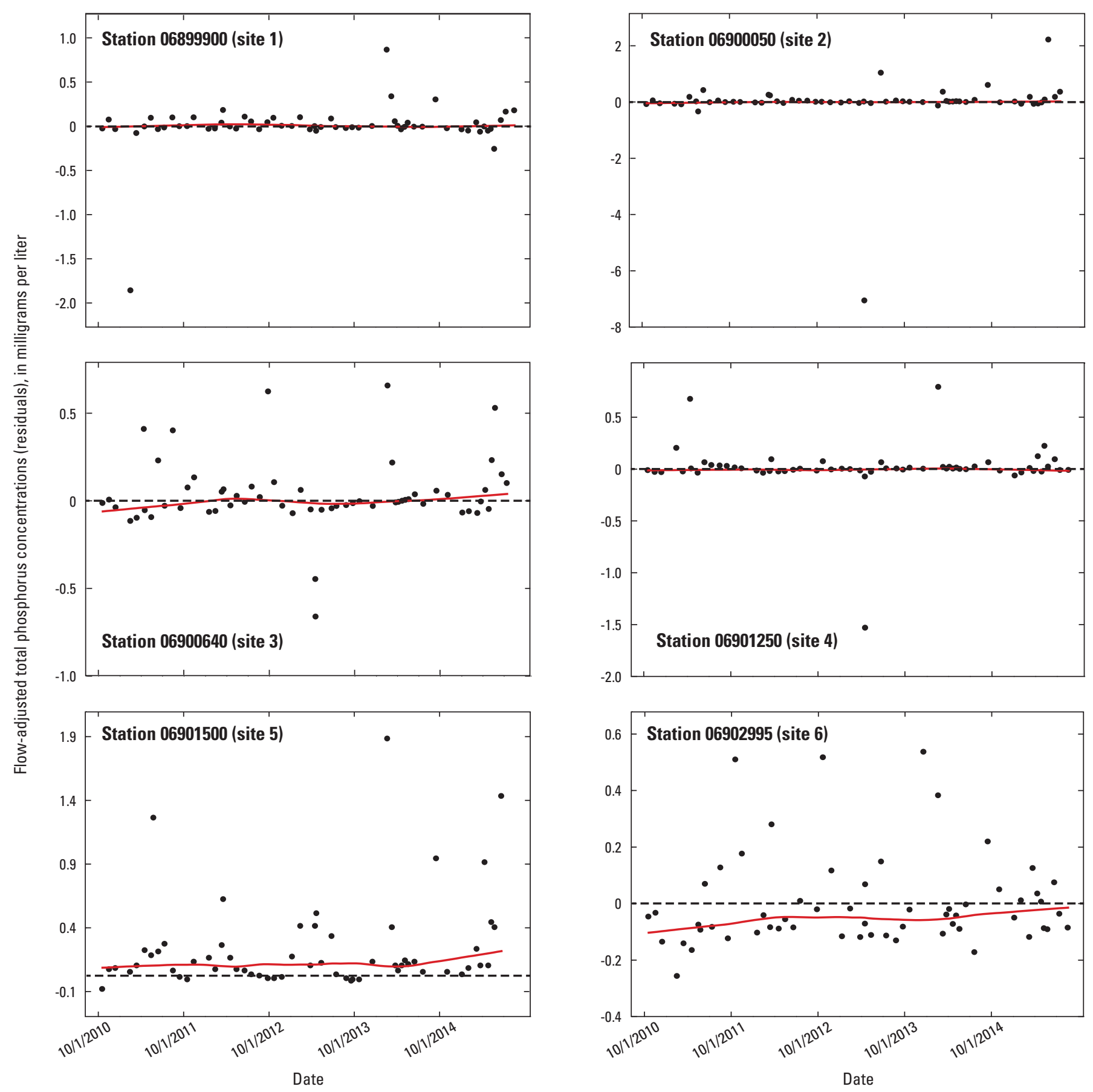

\section{EXPLANATION}

\footnotetext{
_ Locally weighted scatterplot smoothing (LOWESS) fit curve

- - - Zero flow-adjusted concentration line

- Flow-adjusted total phosphorus concentration (residual)
}

Figure 10. Flow-adjusted total phosphorus concentrations for October 1, 2010, through September 30, 2015, at six Mississippi River Basin Healthy Watershed Initiatives sites (sites 1-6; fig. 1; table 1) in the Lower Grand River, Missouri and lowa. 


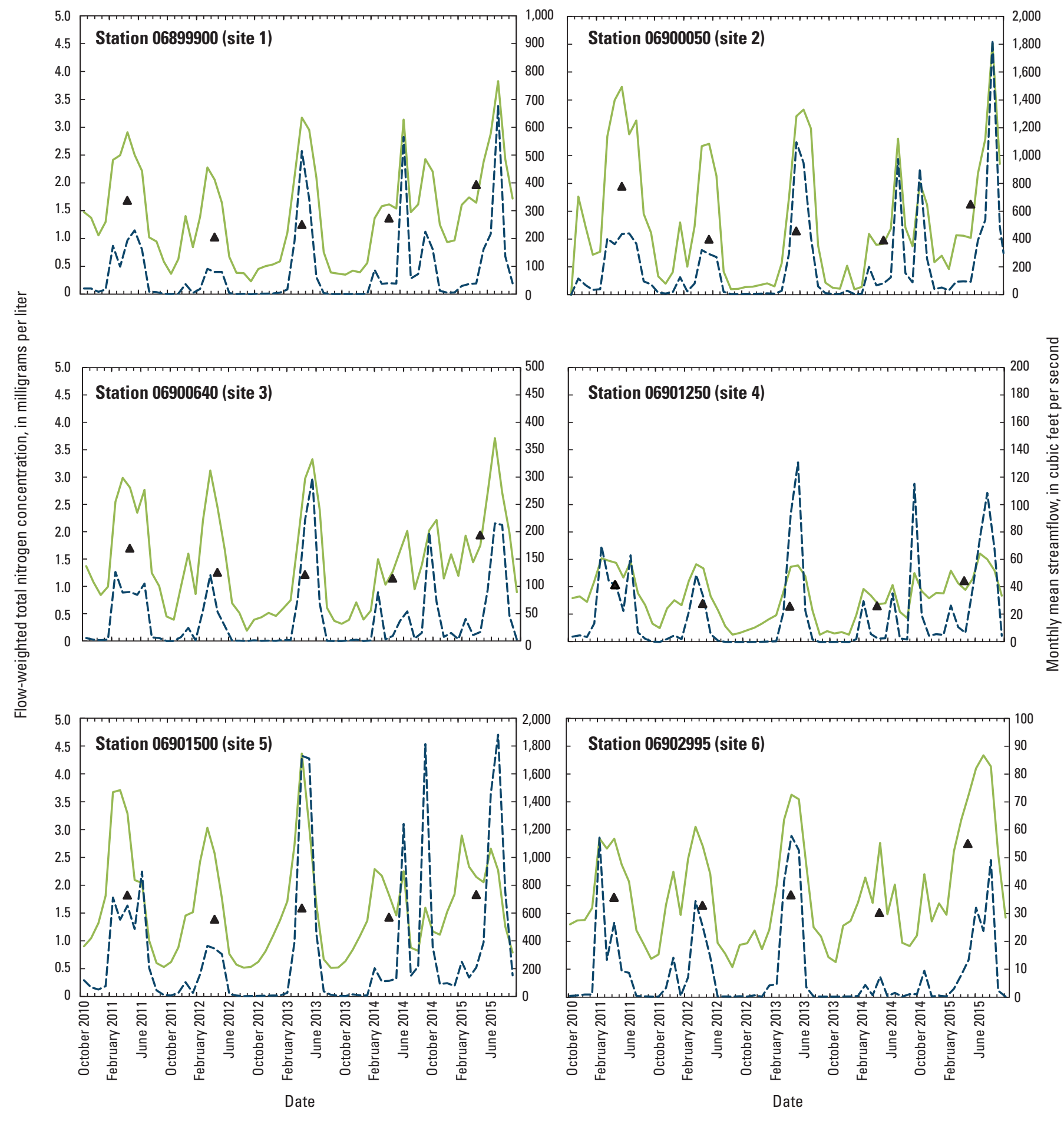

EXPLANATION

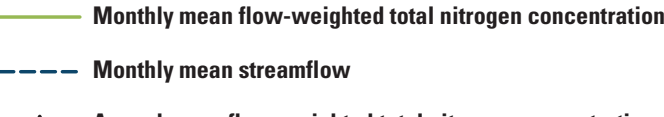

- Annual mean flow-weighted total nitrogen concentration

Figure 11. Temporal changes in monthly mean and annual mean flow-weighted total nitrogen concentrations and monthly mean streamflow at six Mississippi River Basin Healthy Watersheds Initiative sites (sites 1-6; fig. 1; table 1) in the Lower Grand River, Missouri and lowa. 

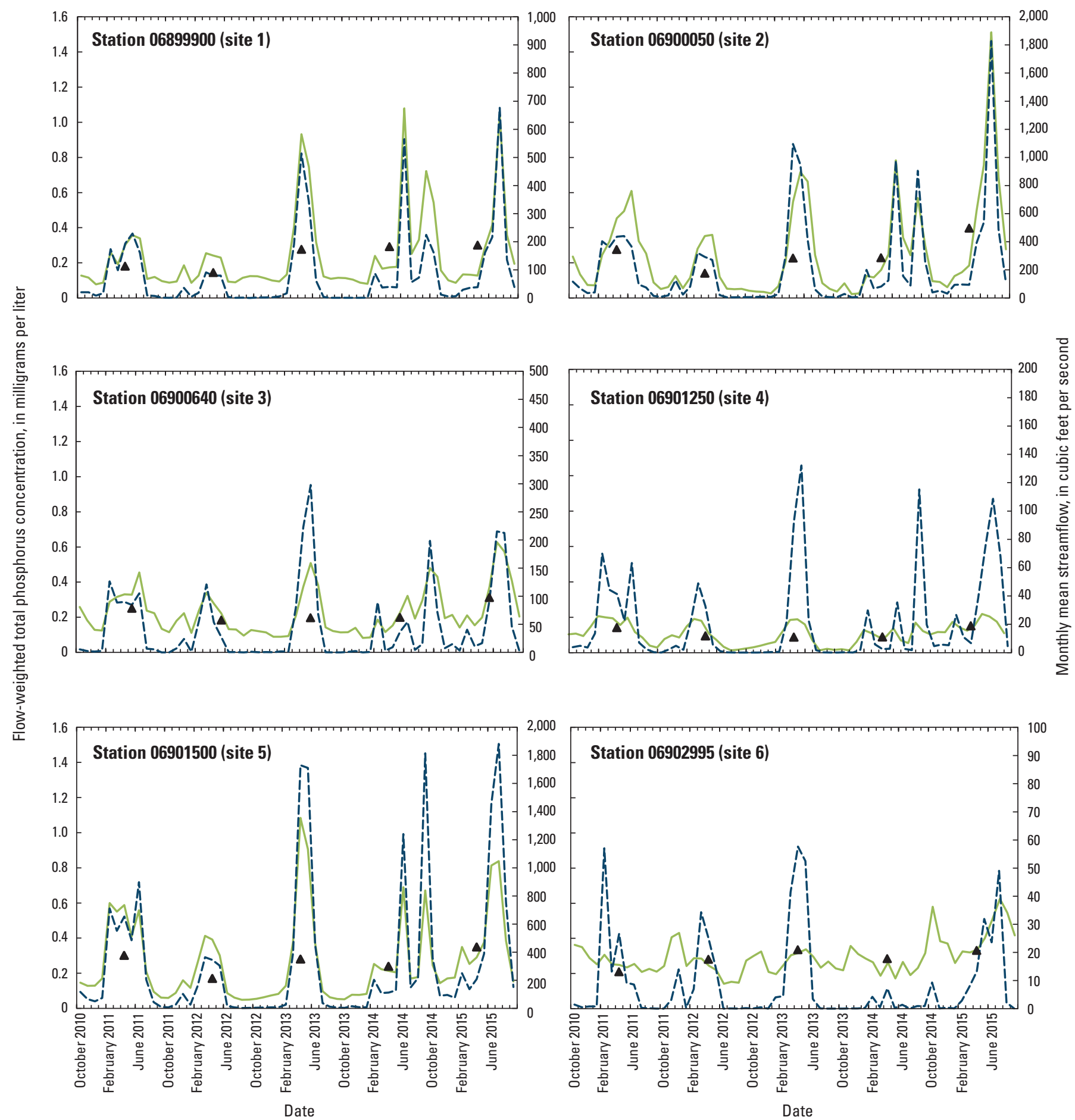

EXPLANATION

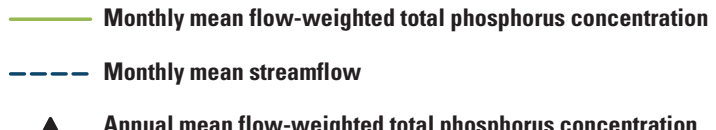

Figure 12. Temporal changes in monthly mean and annual mean flow-weighted total phosphorus concentrations and monthly mean streamflow at six Mississippi River Basin Healthy Watersheds Initiative sites (sites 1-6; fig. 1; table 1) in the Lower Grand River, Missouri and lowa. 
Although generally there were overall increases in annual mean FWTN and FWTP concentrations between October 2010 and September 2015, increases were not substantial (figs. 11, 12). Increases in annual mean FWTN and FWTP between October 2010 and September 2015 were determined at all sites except FWTN at site 2 (figs. 11, 12; appendix 8), which had an overall decrease; however, increases in annual mean FWTN and FWTP concentrations between October 2011 and September 2015 were less than $1 \mathrm{mg} / \mathrm{L}$ and as little as $0.01 \mathrm{mg} / \mathrm{L}$ (appendix 8). Annual mean FWTN increases between October 2010 and September 2015 ranged from 0.46 percent at site 5 to 54 percent at site 6 , and annual mean FWTP increases ranged from 7.0 percent at site 4 to 66 percent at site 1 . An overall increase in annual mean streamflow was determined at all sites and ranged from 18 percent at site 6 to 64 percent at site 2 (appendix 8). Temporal changes in annual mean FWTN and FWTP concentrations were less than $1 \mathrm{mg} / \mathrm{L}$ and generally were similar at all MRBI sites (sites 1-6; figs. 11, 12; appendix 8), which may indicate there has not been a substantial change in TN and TP input sources and the sources may be similar among the watersheds.

Wilkison and Armstrong (2015) estimated monthly TN and TP loads at MRBI sites (sites 1-6) for water years 2011 through 2013 and reported that the cumulative load for February through June accounted for greater than 97 percent of the TN and TP load, and this period coincides with the primary period of spring tillage, crop planting, and surplus soil moisture. More than 91 percent of the total streamflow also occurred during this period for these years. For water years 2011 through 2015, only 71 percent of the cumulative load and 67 percent of the total streamflow occurred during February through June. This likely indicates that increased nitrogen and phosphorus loads are more strongly related to streamflow than to a particular period of the year, indicating runoff, withinbank nutrients that are suspended during higher streamflows, or both are a substantial source of nutrients regardless of timing.

\section{Summary and Conclusions}

Elevated nitrogen and phosphorus concentrations in streams often lead to impairment that can degrade water use for drinking supply, irrigation, recreation, aquatic habitat, and tourism. In 2010, the U.S. Department of Agriculture Natural Resources Conservation Service started a conservation landscape initiative known as the Mississippi River Basin Healthy Watersheds Initiative (MRBI). The MRBI offers financial and technical assistance to agricultural producers in priority watersheds, including the Lower Grand River hydrological unit (hereafter referred to as the "Lower Grand River"), to implement voluntary conservation practices on working agricultural lands with the intention of solving local resource issues on individual participant's land and, in doing so, improving water quality locally and within the Mississippi River watershed.
The purpose of this report is to present the results of a cooperative study by the U.S. Geological Survey (USGS) and Missouri Department of Natural Resources on temporal concentration changes of total nitrogen and total phosphorus in streams within and near the Lower Grand River and possible relations with conservation practices and agricultural activities. The primary objectives of the study were to quantify temporal changes in total nitrogen and total phosphorus concentrations that were adjusted to remove concentration variability caused by streamflow variability and compare longterm temporal total nitrogen and total phosphorus concentration changes among sites and to conservation practices and agricultural activities, which include the annual amount of Conservation Reserve Program acres, annual amount of nitrogen and phosphorus from commercial fertilizer, and annual amount of nitrogen and phosphorus from livestock manure within each watershed.

Temporal changes in annual flow-normalized total nitrogen and total phosphorus concentrations generally were similar among long-term sites (U.S. Geological Survey stations 06817700, 06818000, 06902000, 06905500, and 06934500; sites $7,8,9,10$, and 11), with increases and decreases during similar periods; however, annual flow-normalized total nitrogen and total phosphorus concentrations, timing of inflection points, and slopes of annual flow-normalized total nitrogen and total phosphorus concentration curves varied among sites. Total nitrogen and total phosphorus concentrations have decreased at all long-term sites (sites 7-11) since water year 2008, with the exception of flow-normalized total phosphorus at site 11 , which increased.

Despite increases in funding during 2011-15 for Lower Grand River conservation practices from the MRBI, decreases in flow-normalized total nitrogen and total phosphorus concentrations between water years 2011 and 2015 at site 9 were less than at other long-term sites (sites 7, 8, 10, and 11), which did not receive additional funding. There are several possible explanations why decreases in flow-normalized total nitrogen and total phosphorus concentrations were less at site 9 than other long-term sites despite increased funding for conservation practices from the MRBI. There is an unknown duration of time between implementation of land management changes and an observable change in stream total nitrogen and total phosphorus concentrations that may not have been exceeded. The increases in the amount of conservation practices within the Lower Grand River may not have been substantial enough to reduce stream total nitrogen and total phosphorus concentrations in the entire Grand River watershed. The specific types of conservation practices that were put into effect in the Lower Grand River during this period may not have a substantial effect on reducing nutrients.

The relative differences in the magnitude of flow-normalized concentrations among selected long-term sites (sites 7, 9, and 10) are directly related to the amount of agricultural land use in these watersheds. Annual flow-normalized total nitrogen and total phosphorus concentrations at selected long-term Missouri River tributary sites (sites 7, 9, and 10) consistently 
were greatest at site 7 and lowest at site 10 , with total nitrogen and total phosphorus concentrations at site 9 in between these two sites. Nodaway River (site 7) watershed has the greatest percent of agricultural land use of the selected long-term sites, Chariton River (site 10) watershed has the lowest percentage of agricultural land use of the selected long-term sites, and the percentage of agricultural land use in the Grand River (site 9) watershed also is in between that of sites 7 and 10 .

Relations between CRP acres and flow-normalized total nitrogen and total phosphorus concentrations were either not statistically significant ( $p$-value greater than $[>] 0.05)$, not strong (absolute value of correlation coefficient $[r]$ less than $[<] 0.80$ ) when significant ( $p$-value $\leq 0.05$ ), or strong significant relations (absolute values of $r \geq 0.80$ and $p$-value $\leq 0.05$ ) were in the opposite direction than expected). This may indicate that changes in CRP acres alone have not had a substantial effect on stream total nitrogen and total phosphorus concentrations; other landscape activities, runoff, within-bank nutrients that are suspended during higher streamflows, or a combination of these have had a greater effect on stream TN and TP concentrations; or that the lag time between taking land out of production and observed reductions in stream TN and TP concentrations is substantial within these watersheds and obscures results.

Significant $(p$-value $\leq 0.05)$ relations were determined between annual nitrogen and phosphorus concentrations from commercial fertilizer and flow-normalized total nitrogen and total phosphorus concentrations for site 9 but were not strong (absolute value of $r<0.80$ ), and nitrogen relations were inversely related (negative $r$ ), which would not be expected. Significant relations were not determined at other selected long-term sites (sites 7 and 10). These results indicate that changes in annual nitrogen and phosphorus from commercial fertilizer alone within these watersheds are not strongly (absolute value of $r<0.80$ ) correlated with changes in flow-normalized total nitrogen and total phosphorus concentrations at these sites or that the methods used to estimate annual nitrogen and phosphorus from commercial fertilizer for each watershed were not representative of the amount of commercial fertilizer applied within the watershed.

A significant ( $p$-value $\leq 0.05$ ) and strong (absolute value of $r \geq 0.80$ ), direct (positive $r$ ) relation was determined between nitrogen concentrations from total livestock manure and flow-normalized total nitrogen concentrations at site 9 but not between phosphorus concentrations from total livestock manure and flow-normalized phosphorus concentrations. Site 9 was the only site that had substantial total livestock manure and flow-normalized total nitrogen and total phosphorus concentration data. Significant ( $p$-value $\leq 0.05$ ), direct (positive $r$ ) relations were determined between nitrogen from cattle manure and flow-normalized total nitrogen concentrations at all selected long-term sites (sites 7, 9, and 10), and relations were strong (absolute value of $r \geq 0.80$ ) for the Grand River and Chariton River (sites 9 and 10) watersheds. The only significant $(p$-value $\leq 0.05)$ relation between phosphorus from cattle manure and flow-normalized total phosphorus concentrations was for site 10, but relations were not strong. These results indicate that total livestock and cattle manure have a greater effect on stream nitrogen concentrations than phosphorus concentrations, and livestock manure may be a substantial source of nitrogen in streams especially within the Grand River and Chariton River watersheds.

Temporal changes in flow-adjusted total nitrogen and flow-adjusted total phosphorus concentrations were displayed at some MRBI sites (U.S. Geological Survey stations 06899900, 06900050, 06900640, 06901250, 06901500, and 06902995; sites 1, 2, 3, 4, 5, and 6) but changes were not substantial. The lack of substantial temporal change in flowadjusted total nitrogen and total phosphorus concentrations at MRBI sites during the sample period indicates factors besides streamflow variability did not have a substantial effect on sample total nitrogen and total phosphorus concentrations.

Temporal changes in monthly mean flow-weighted total nitrogen and total phosphorus concentrations generally follow streamflow with flow-weighted total nitrogen and total phosphorus concentrations increasing with streamflow. This indicates runoff, within-bank nutrients that are suspended during higher streamflows, or both are major sources of nitrogen and phosphorus and have more effect on stream total nitrogen and total phosphorus concentrations than consistent point sources or groundwater sources.

Although there were generally overall increases in annual mean flow-weighted total nitrogen and flow-weighted total phosphorus concentrations between October 2010 and September 2015, these increases were less than 1 milligram per liter and as little as 0.01 milligram per liter. Also, an overall increase in annual mean streamflow was determined at all sites. Temporal changes in annual mean flow-weighted total nitrogen and total phosphorus concentrations generally were similar at all MRBI sites (sites 1-6), which may indicate there has not been a substantial change in nitrogen and phosphorus input sources and the sources may be similar among the watersheds.

Monthly total nitrogen and total phosphorus loads at MRBI sites (sites 1-6) for water years 2011 through 2013 were determined in a previous study, which reported that the cumulative load for February through June accounted for greater than 97 percent of the total nitrogen and total phosphorus load, and this period coincides with the primary period of spring tillage, crop planting, and surplus soil moisture. More than 91 percent of the total streamflow, however, also occurred during this period for these years. For water years 2011 through 2015, only 71 percent of the cumulative load and 67 percent of the total streamflow occurred during February through June. This likely indicates that increased nitrogen and phosphorus loads are more strongly related to streamflow than to a particular period of the year, indicating runoff, withinbank nutrients that are suspended during higher streamflows, or both are a substantial source of nutrients regardless of timing. 


\section{References Cited}

Akaike, Hirotugu, 1981, Likelihood of a model and information criterion: Journal of Econometrics, v. 16, no. 1, p. 3-14. [Also available at https://doi.org/10.1016/03044076(81)90071-3.]

Caraco, N.F. and Cole, J.J., 1999, Human impact on nitrate export-An analysis using major world rivers: Ambio, v. 28, no. 2, p. 167-170.

Claassen, Roger; Cattaneo, Andrea; and Johansson, Robert, 2008, Cost-effective design of agri-environmental payment programs - U.S. experience in theory and practice: Ecological Economics, v. 65, no. 4, p. 737-752. [Also available at https://doi.org/10.1016/j.ecolecon.2007.07.032.]

Cleveland, W.S., and Devlin, S.J., 1988, Locally weighted regression-An approach to regression analysis by local fitting: Journal of the American Statistical Association, v. 83, no. 403 , p. 596-610. [Also available at http://www.jstor.org/ stable/2289282.]

Crawford, C.G., Slack, J.R., and Hirsch, R.M., 1983, Nonparmaetric test for trends in water-quality data using the statistical analysis system: U.S. Geological Survey OpenFile Report 83-550, 102 p. [Also available at https://pubs. er.usgs.gov/publication/ofr83550.]

Creekmore, L.H., 1999, Algal toxins, chap. 36 of Friend, Milton, and Franson, J.C., eds., Field manual of wildlife diseases - General field procedures and diseases of birds: U.S. Geological Survey Information and Technology Report 1999-001, p. 263-266.

Farm Service Agency [FSA], variously dated (a), Conservation Reserve Program statistics: U.S. Department of Agriculture, Farm Service Agency web page, accessed October 24, 2016, at https://www.fsa.usda.gov/programsand-services/conservation-programs/reports-and-statistics/ conservation-reserve-program-statistics/index.

Farm Service Agency [FSA], variously dated (b), Programs and services: U.S. Department of Agriculture, Farm Service Agency web page, accessed October 24, 2016, at https:// www.fsa.usda.gov/programs-and-services/index.

Femmer, S.R., 2011, Algal community characteristics and response to nitrogen and phosphorus concentrations in streams in the Ozark Plateaus, southern Missouri, 1993-95 and 2006-07: U.S. Geological Survey Scientific Investigations Report 2011-5209, 25 p. [Also available at https:// pubs.usgs.gov/sir/2011/5209/.]

Fishman, M.J., ed., 1993, Method of analysis by the U.S. Geological Survey National Water Quality Laboratory-Determination of inorganic and organic constituents in water and fluvial sediments: U.S. Geological Survey Open-File Report 93-125, 217 p. [Also available at https://pubs.er.usgs.gov/ publication/ofr93125.]
Fishman, M.J., Raese, J.W., Gerlitz, C.N., and Husband, R.A., 1994, U.S. Geological Survey approved inorganic and organic methods for the analysis of water and fluvial sediment, 1954-94: U.S. Geological Survey Open-File Report 94-351, 55 p. [Also available at https://pubs.er.usgs.gov/ publication/ofr94351.]

Garrett, J.D., 2012, Concentrations, loads, and yields of selected constituents from major tributaries of the Mississippi and Missouri Rivers in Iowa, water years 2004-2008: U.S. Geological Survey Scientific Investigations Report 2012-5240, 61 p. [Also available at https://pubs.usgs.gov/ $\operatorname{sir} / 2012 / 5240 /$.

Goolsby, D.A., Battaglin, W.A., Lawrence, G.B., Artz, R.S., Aulenbach, B.T., Hooper, R.P., Keeney, D.R., and Stensland, G.J., 1999, Flux and sources of nutrients in the Mississippi-Atchafalaya River Basin-Topic 3 report for the integrated assessment on hypoxia in the Gulf of Mexico: Silver Spring, Md., National Oceanic and Atmospheric Administration Coastal Ocean Office, Coastal Ocean Program Decision Analysis Series No. 17, 130 p.

Gronberg, J.M., and Spahr, N.E., 2012, County-level estimates of nitrogen and phosphorus from commercial fertilizer for the conterminous United States, 1987-2006: U.S. Geological Survey Scientific Investigations Report 2012-5207, 20 p. [Also available at https://pubs.usgs.gov/ $\operatorname{sir} / 2012 / 5207 /$.

Heimann, D.C., Sprague, L.A., and Blevins, D.W., 2011, Trends in suspended-sediment loads and concentrations in the Mississippi River Basin, 1950-2009: U.S. Geological Survey Scientific Investigations Report 2011-5200, 33 p. [Also available at https://pubs.usgs.gov/sir/2011/5200/.]

Hirsch, R.M., Moyer, D.L. and Archfield, S.A., 2010, Weighted Regressions on Time, Discharge, and Season (WRTDS), with an application to Chesapeake Bay River inputs: Journal of the American Water Resources Association, v. 46, no. 5, p. 857-880. [Also available at https://doi. org/10.1111/j.1752-1688.2010.00482.x.]

Homer, C.G.; Dewitz, J.A.; Yang, Limin; Jin, Suming; Danielson, Patrick; Xian, George; Coulston, John; Herold, N.D.; Wickham, J.D.; and Megown, Kevin, 2015, Completion of the 2011 National Land Cover Database for the conterminous United States - Representing a decade of land cover change information: Photogrammetric Engineering and Remote Sensing, v. 81, no. 5, p. 345-354.

Howarth, R.W., Billen, G., Swaney, D., Townsend, A., Jaworski, N., Lajtha, K., Downing, J.A., Elmgren, R., Caraco, N., Jordan, T., Berendse, F., Freney, J., Kudeyarov, V., Murdoch, P., and Zhao-Liang, Z., 1996, Regional nitrogen budgets and riverine $\mathrm{N}$ and $\mathrm{P}$ fluxes for the drainages to the North Atlantic Ocean-Natural and human influences: Biogeochemistry [Kluwer Academic Publishers], v. 35, no. 1, p. 75-139. [Also available at https://doi.org/10.1007/ BF02179825.] 
Johansson, R.C., and Cattaneo, A., 2006, Indices for working land conservation-Form affects function: Review of Agricultural Economics, v. 28, no. 4, p. 567-584. [Also available at https://doi.org/10.1111/j.1467-9353.2006.00323.x.]

Langland, M.J., Blomquist, J.D., Sprague, L.A., and Edwards, R.E., 2000, Trends and status of flow, nutrients, and sediments for selected nontidal sites in the Chesapeake Bay watershed, 1985-98: U.S. Geological Survey Open-File Report 99-451, 46 p.

Meals, D.W. and Dressing, S.A., 2008, Lag time in water quality response to land treatment: Fairfax, Va., Developed for the U.S. Environmental Protection Agency by Tetra Tech, Inc., National Nonpoint Source Monitoring Program Tech Notes 4, 16 p. [Also available at https://www.epa.gov/ sites/production/files/2016-05/documents/tech_notes_4_ dec2013_lag.pdf.]

Missouri Agricultural Experimentation Station, variously dated, Fertilizer and plant food tonnages shipped for use in Missouri since 1949: Columbia, Mo., Missouri Agricultural Experimentation Station, Plant Food Control Service web page, accessed July 21, 2016, at http://aes.missouri.edu/ pfcs/fert/index.stm.

Missouri Department of Natural Resources, variously dated, Soil and Water Conservation Program: Missouri Department of Natural Resources, Soil and Water Conservation Program web page, accessed July 21, 2016, at https://dnr. mo.gov/env/swcp/.

Nash, J.E., and Sutcliffe, J.V., 1970, River flow forecasting through conceptual models part I-A discussion of principles: Journal of Hydrology, v. 10, no. 3, p. 282-290. [Also available at https://doi.org/10.1016/0022-1694(70)90255-6.]

National Agricultural Statistics Service, variously dated, Quick stats: U.S. Department of Agriculture, National Agricultural Statistics Service, Quick Stats web page, accessed October 26, 2016, at https://quickstats.nass.usda.gov/.

Natural Resources Conservation Service [NRCS], variously dated (a), Mississippi River Basin Healthy Watersheds Initiative: U.S. Department of Agriculture, Natural Resources Conservation Service web page, accessed October 26, 2016, at https://www.nrcs.usda.gov/wps/portal/nrcs/detailfull/ national/home/?cid=stelprdb1048200.

Natural Resources Conservation Service [NRCS], variously dated (b), NRCS conservation programs: U.S. Department of Agriculture, Natural Resources Conservation Service web page, available at https://www.nrcs.usda.gov/wps/portal/nrcs/main/national/programs/.
Patton, C.J., and Kryskalla, J.R., 2003, Methods of analysis by the U.S. Geological Survey National Water Quality Laboratory-Evaluation of alkaline persulfate digestion as an alternative to Kjeldahl digestion for determination of total and dissolved nitrogen and phosphorus in water: U.S. Geological Survey Water-Resources Investigations Report 03-4174, 33 p. [Also available at https://nwql.usgs.gov/ WRIR-03-4174.shtml.]

Patton, C.J., and Kryskalla, J.R., 2011, Colorimetric determination of nitrate plus nitrite in water by enzymatic reduction, automated discrete analyzer methods: U.S. Geological Survey Techniques and Methods, book 5, chap. B8, 34 p. [Also available at https://pubs.usgs.gov/tm/05b08/.]

Patton, C.J., and Truitt, E.P., 1992, Methods of analysis by the U.S. Geological Survey National Water Quality Laboratory_-Determination of total phosphorus by a Kjeldahl digestion method and an automated colorimetric finish that includes dialysis: U.S. Geological Survey Open-File Report 92-146, 39 p. [Also available at https:/nwql.usgs.gov/rpt. shtml?OFR-92-146.]

Patton, C.J., and Truitt, E.P., 2000, Methods of analysis by the U.S. Geological Survey National Water Quality Laboratory-Determination of ammonium plus organic nitrogen by a Kjeldahl digestion method and an automated photometric finish that includes digest cleanup by gas diffusion: U.S. Geological Survey Open-File Report 2000-170, 31 p. [Also available at https://pubs.er.usgs.gov/publication/ofr00170.]

Rabalais, N.N., Turner, R.E., and Wiseman, W.J., 2002, Gulf of Mexico hypoxia, a.k.a. "The Dead Zone": Annual Review of Ecology, Evolution, and Systematics, v. 33, p. 235-263. [Also available at https://doi.org/10.1146/ annurev.ecolsys.33.010802.150513.]

Rickert, D.A., 1985, Compensation for discharge in detecting trends in water quality: U.S. Geological Survey Quality of Water Branch Memorandum No. 85.17.

Ruddy, B.C., Lorenz, D.L., and Mueller, D.K., 2006, Countylevel estimates of nutrient inputs to the land surface of the conterminous United States, 1982-2001: U.S. Geological Survey Scientific Investigations Report 2006-5012, 17 p. [Also available at https://pubs.usgs.gov/sir/2006/5012/.]

Runkel, R.L., Crawford, C.G., and Cohn, T.A., 2004, Load estimator (LOADEST) - A FORTRAN program for estimating constituent loads in streams and rivers: U.S. Geological Survey Techniques and Methods, book 4, chap. A5, 69 p. [Also available at https://pubs.usgs.gov/tm/2005/ tm4A5/.] 
Schertz, T.L., Alexander, R.B., and Ohe, D.J., 1991, The Computer Program Estimate Trend (ESTREND), a system for the detection of trends in water-quality data: U.S. Geological Survey Water-Resources Investigations Report 91-4040, 63 p. [Also available at https://pubs.usgs.gov/wri/ wri91-4040/.]

Sprague, L.A., and Gronberg, J.M., 2013, Estimated anthropogenic nitrogen and phosphorus inputs to the land surface of the conterminous United States - 1992, 1997, and 2002: U.S. Geological Survey Scientific Investigations Report 2012-5241, 14 p. [Also available at https://pubs.usgs.gov/ $\operatorname{sir} / 2012 / 5241 /$.

Sprague, L.A., Hirsch, R.M., and Aulenbach, B.T., 2011, Nitrate in the Mississippi River and its tributaries, 1980 to 2008-Are we making progress?: Environmental Science \& Technology, v. 45, no. 17, p. 7209-7216. [Also available at https://doi.org/10.1021/es201221s.]

Sprague, L.A., Mueller, D.K., Schwarz, G.E., and Lorenz, D.L., 2009, Nutrient trends in streams and rivers of the United States, 1993-2003: U.S. Geological Survey Scientific Investigations Report 2008-5202, 196 p. [Also available at https://pubs.usgs.gov/sir/2008/5202/.]

Scientific and Technical Advisory Committee [STAC], 2013, Incorporating lag-times Into the Chesapeake Bay Program: Edgewater, Md., Chesapeake Bay Program, STAC Publication No. 13-004, 66 p.

Stenback, G.A., Crumpton, W.G., Schilling, K.E., and Helmers, M.J., 2011, Rating curve estimation of nutrient loads in Iowa rivers: Journal of Hydrology, v. 396, nos. 1-2, p. 158-169. [Also available at https://doi.org/10.1016/j. jhydrol.2010.11.006.]
U.S. Department of Agriculture [USDA], variously dated, Census of agriculture: U.S. Census of Agriculture web page, accessed August 1, 2016, at https://www.agcensus.usda.gov/ Publications/.

U.S. Environmental Protection Agency [EPA], 1993, Method 365.1, revision 2.0 - Determination of phosphorus by semiautomated colorimetry: Cincinnati, Ohio, U.S. Environmental Protection Agency, 17 p. [Also available at https:// www.epa.gov/sites/production/files/2015-08/documents/ method_365-1_1993.pdf.]

U.S. Environmental Protection Agency [EPA], variously dated (a), National water quality inventory report to Congress:

U.S. Environmental Protection Agency web page, accessed May 25, 2016, at https://www.epa.gov/waterdata/nationalwater-quality-inventory-report-congress.

U.S. Environmental Protection Agency [EPA], variously dated (b), EPA State Combined CSV download files: U.S. Environmental Protection Agency web page, digital data, accessed August 23, 2016, at https://www.epa.gov/enviro/ epa-state-combined-csv-download-files.

U.S. Geological Survey [USGS], variously dated, National field manual for the collection of water-quality data: U.S. Geological Survey Techniques of Water-Resources Investigations, book 9, chaps. A1-A10. [Also available at https:// pubs.water.usgs.gov/twri9A.]

Van Meter, K.J., and Basu, N.B., 2015, Catchment legacies and time lags - A parsimonious watershed model to predict the effects of legacy storage on nitrogen export: PLOS ONE, v. 10, no. 5, art. e0125971. [Also available at https:// doi.org/10.1371/journal.pone.0125971.]

Wilkison, D.H., and Armstrong, D.J., 2015, Water-quality assessment of the Lower Grand River Basin, Missouri and Iowa, USA, in support of integrated conservation practices: River Research and Applications, v. 32, no. 4, p. 583-596. [Also available at https://doi.org/10.1002/rra.2887.] 


\section{Appendixes 1-8. Supplemental Data for Selected Sites in Missouri and lowa}

Appendixes 1-8 are available for download as an Excel file at https://doi.org/10.3133/sir20175067. 
Publishing support provided by:

Rolla and West Trenton Publishing Service Centers

For additional information concerning this publication, contact: Director, USGS Missouri Water Science Center 1400 Independence Road

Rolla, M0 65401

(573) 308-3667

Or visit the Missouri Water Science Center web site at: https://mo.water.usgs.gov 
